\title{
Creating a Disaggregated CGE Model for Trade Policy Analysis: GTAP-MVH
}

\section{CoPS Working Paper No. G-291, April 2019}

\author{
Peter B. Dixon, \\ Maureen Rimmer \\ And \\ Nhi Tran \\ Centre of Policy Studies, \\ Victoria University
}





\title{
Creating a disaggregated CGE model for trade policy analysis: GTAP-MVH
}

By

\author{
Peter B. Dixon, Maureen Rimmer and Nhi Tran
}

Centre of Policy Studies

April 30, 2019

\begin{abstract}
:
Thousands of economists spread across almost every country use the GTAP model to analyze trade policies including trade wars and trade agreements. GTAP has an impressive regional coverage (140 countries) but the standard commodity coverage (57 commodities/industries) can cause frustration when tariffs on narrowly defined products are being negotiated. This paper sets out a method for disaggregating commodities/industries in computable general equilibrium models such as GTAP and applies it to GTAP's motor vehicle sector. The method makes use of readily available highly disaggregated trade data supplemented by detailed input-output data where available and data from a variety of other sources such as commercial market reports.
\end{abstract}

JEL codes: C68; F13; F14; F17

Key words: GTAP disaggregation; motor vehicle sector; intra-NAFTA tariffs

\section{Acknowledgements:}

Worked out most of the ideas in this paper during a visit in April/May 2018 to the Research Institute for Global Value Chains at the University of International Business and Economics, Beijing. We thank Professor Yang Jun and Professor Zhi Wang for being wonderful hosts and for providing a highly supportive research environment.

We thank Global Affairs Canada for financial support that made it possible for us to complete the project. Shenjie Chen and Jeff Bennett from Global Affairs provided valuable advice. However, neither they nor their employer is responsible for any part of this paper. 


\section{Table of contents}

1. Introduction 3

2. Transforming standard GTAP into GTAP-MVH 3

2.1 Disaggregation theory 5

$\begin{array}{ll}2.2 & \text { Disaggregation data } \\ 2.30\end{array}$ 2.3 Sales matrices for disaggregated mvh products: outcomes of the
disaggregation procedures

3. Illustrative GTAP-MVH simulations 14

4. Concluding remarks 27

$\begin{array}{lr}\text { References } & 28\end{array}$ 


\section{Introduction}

For over fifty years, computable general equilibrium (CGE) models have been used in analysing the effects of changes in trade policies and have now become a standard tool. ${ }^{1}$ CGE-based analyses have been helpful in identifying indirect effects. While it may be obvious that the motor vehicle industry in the U.S. benefits from higher tariffs on imported finished vehicles, it may not be so obvious that export-oriented activities such as U.S. higher educational services are harmed. As captured by a CGE model, the vehicle industry and higher education are linked via the real exchange rate. Less imported vehicles strengthens the exchange rate and hurts the export prospects of industries such as higher education.

The world's best known and most widely used CGE trade model is GTAP2. Its full database consists of mutually consistent input-output tables, trade flows and protection rates in 140 countries. Documentation of GTAP's theory and data can be found in Hertel (1997), Corong et al. (2017) and Aguiar et al. (2016). Flexible aggregation programs are available to form versions of GTAP with manageable regional disaggregation highlighting regions of interest for particular applications. Later in this paper we describe simulations with a 10-region version of GTAP. The regions are shown in Table 1.1.

While GTAP's regional detail is more than adequate for most purposes, the standard commodity/industry detail does not fully meet the requirements for convincing analysis to support contemporary trade negotiations. The database for the standard GTAP model distinguishes 57 sectors. At this level of disaggregation, key sectors in trade negotiations are often represented as a single amalgam of activities at various stages of a supply chain. For example, the production of all motor vehicle products in each country is represented in standard GTAP as a single sector, denoted by mvh. This means that there is no recognition of differences between brakes, transmissions, interior trimming, finished vehicles etc in input requirements, sales patterns and rates of protection.

In section 2, we set out a method for disaggregating commodities/industries in computable general equilibrium models such as GTAP and apply it to GTAP's motor vehicle sector. The method makes use of readily available highly disaggregated trade data supplemented by detailed input-output data where available and data from a variety of other sources such as commercial market reports. Using our disaggregation method, we split GTAP's mvh sector into 9 commodities/industries to create GTAP-MVH. In section 3 we describe illustrative simulations with GTAP-MVH, showing the effects of tariffs imposed by NAFTA countries on finished vehicles while leaving tariffs on parts unchanged. Concluding remarks are in section 4.

\section{Transforming standard GTAP into GTAP-MVH}

In simplified form (omitting taxes and international transport margins), the database for the GTAP model is represented by Table 2.1. Part A is often referred to as the NATIONAL matrix for region $\mathrm{d}$. It shows flows of domestic commodities and imported commodities (undifferentiated by region of origin) to industries in region $\mathrm{d}$ and to final users excluding exports. It also shows the use of primary factors by industries in region d. Part B is often referred to as the TRADE matrix. This is a three dimensional array. For each commodity, it shows sources and destinations of international trade flows. The data in the two parts of the table satisfy two balance conditions. First, the jth row sum in the imports part of d's NATIONAL matrix equals the sum across sources of d's imports of $j$ from the TRADE

\footnotetext{
1 Early contributions include Evans (1972), Deardorff et al. (1977) and Dixon et al. (1977 and 1982).

2 GTAP stands for Global Trade Analysis Project. The model was created by the GTAP research group at Purdue University.
} 
Table 1.1. Regions in the GTAP-MVH model

\begin{tabular}{c|l}
\hline No. & Regions \\
\hline 1 & USA \\
2 & Canada \\
3 & Mexico \\
4 & Japan \\
5 & South Korea \\
6 & China \\
7 & Germany \\
8 & EU26 (= EU-28 less Germany and the UK) \\
9 & United Kingdom \\
10 & Rest of the World \\
\hline
\end{tabular}

matrix (sum of jth column). Second, the jth row sum in the domestic part of d's NATIONAL matrix plus d's exports of $j$ from the TRADE matrix (sum of jth row) equals d's output of $j$ obtained as the jth column sum in the industry part of d's NATIONAL matrix.

In Table 2.1, without loss of generality, we have marked motor vehicles (mvh) as the first industry and first commodity. The disaggregation task described in this section is to replace the mvh part of the TRADE matrix with matrices for each sub-mvh commodity and to split the mvh column and the two mvh rows in the NATIONAL matrix for each country d into sub-mvh industries and commodities. As will become apparent in subsection 2.1, (a) to (e) in the NATIONAL matrix represent different disaggregation formulas. These formulas split GTAP data items: the disaggregated database reproduces the original database when reaggregated.

In the rest of this section, we describe the theory (subsection 2.1) and data (subsection 2.2) by which we disaggregated GTAP's mvh industry/commodity into 9 NAICS-based industries/commodities. We also briefly describe some disaggregation results (subsection 2.3). As mentioned already, we performed the disaggregation on a 10-region version of GTAP (see Table 1.1). It was also convenient from a computational and data-management point of view to aggregate GTAP's 56 non-mvh industries/commodities into 17. For example, in GTAP-MVH the 12 GTAP agricultural industries/commodities are aggregated into one. The full list of $26(=9+17)$ industries/commodities in GTAP-MVH is in Table 2.2, with the disaggregated mvh industries/commodities shaded and in bold type.

Highly disaggregated trade data are available for almost every country to provide a basis for disaggregation of TRADE matrices. By contrast, the input-output matrices that underlie NATIONAL matrices are usually published at a relatively aggregated level, much more aggregated than the trade data. In our disaggregation theory, we start by assuming that satisfactory disaggregated TRADE matrices can be formed, although as we will see in subsection 2.2, this may require considerable work on concording commodity/industry classifications between trade and input-output data. To disaggregate NATIONAL matrices we need data for disaggregated commodities/industries on outputs, inputs and sales. For our mvh disaggregation task, direct data for these variables is not available for most countries. We estimate the missing data taking account of what is available: trade data and detailed input-output data for some key countries. The estimates become the basis for splitting shares that are applied to the original GTAP data. 
Table 2.1 Database for a GTAP model

Part A. NATIONAL matrix for region d

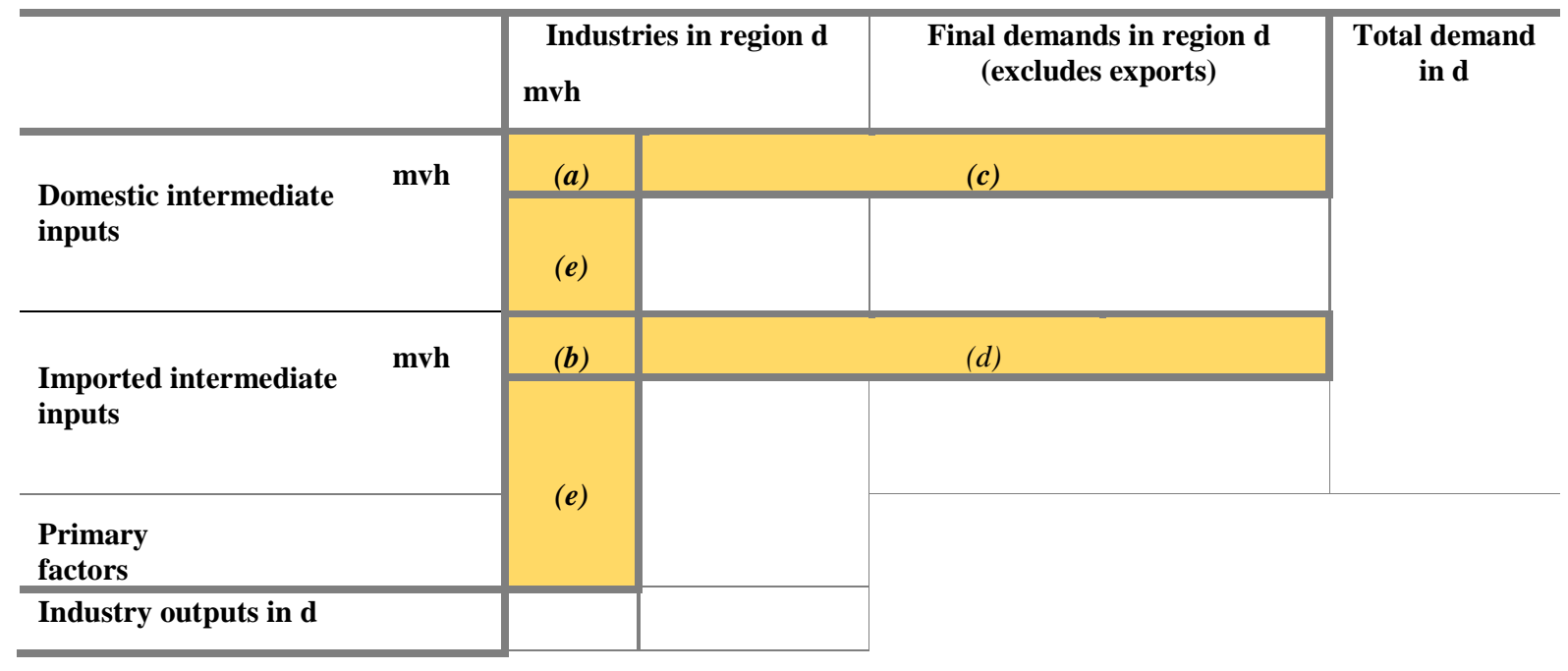

Part B. TRADE matrix for commodity $c$

\begin{tabular}{|c|c|c|c|c|c|c|}
\hline & & \multicolumn{5}{|c|}{ Destination region } \\
\hline & & U.S. & Canada & $\ldots$ & $\ldots$ & ROW \\
\hline \multirow{4}{*}{$\begin{array}{l}\text { Source } \\
\text { region }\end{array}$} & $\begin{array}{c}\text { U.S. } \\
\text { Canada }\end{array}$ & & & \multirow{4}{*}{$\begin{array}{c}\text { International flows } \\
\text { of commodity c } \\
\text { (zero diagonals) }\end{array}$} & & \\
\hline & $\begin{array}{l}\cdots \\
\cdots\end{array}$ & & & & & \\
\hline & $\cdots$ & & & & & \\
\hline & ROW & & & & & \\
\hline
\end{tabular}

\subsection{Disaggregation theory}

The central part of our disaggregation theory is a system of equations in which we treat trade flows in disaggregated products as observable exogenous variables. This allows us to make full use of comprehensive disaggregated trade data published by the United Nations. The equations also rely on the availability of detailed input-output data for one or more leading producer countries in the sector being disaggregated.

In the case of mvh, the inputs to the disaggregation equation system are data (adjusted to 2015 levels where required) on: trade flows for disaggregated mvh products; U.S. and Canadian input-output data for these products; and initial estimates (described in subsection 2.2) for outputs of and demands for mvh products in regions other than the U.S. and Canada. 
Table 2.2. Sectors in the GTAP-MVH model

\begin{tabular}{|c|c|c|c|c|}
\hline No. & Sectors & Description & NAICS codes & Original GTAP sectors \\
\hline 1 & Agriculture & Agriculture & $1111-1123$ & $\begin{array}{l}\text { Paddy rice; Wheat; Cereal grains nec; Vegetables, fruits, nuts; Oil seeds; } \\
\text { Sugar cane, sugar beet; Plant-based fibres; Crops nec; Bovine cattle, } \\
\text { sheep and goats, horses; Animal products nec; Raw milk; Wool, silk- } \\
\text { worm cocoons. }\end{array}$ \\
\hline 2 & ForFishMinng & Forestry, fishery and mining & $1130-2131$ & Forestry; Fishing; Coal, oil, gas; Minerals nec. \\
\hline 3 & FoodBevTob & $\begin{array}{l}\text { Food, beverages and tobacco } \\
\text { products }\end{array}$ & $3111-3122$ & $\begin{array}{l}\text { Bovine meat products; Meat products nec; Vegetable oils and fats; Dairy } \\
\text { products; Processed rice; Sugar; Food products nec; Beverages and } \\
\text { tobacco products. }\end{array}$ \\
\hline 4 & TCF & Textile, clothing and footwear & $3131-3160$ & Textiles; Wearing apparel; Leather products. \\
\hline 5 & WoodProd & Wood products & $3211-3219$ & Wood products. \\
\hline 6 & NMetMinrlPrd & Non-metal mineral materials & $3271-3279$ & Mineral products nec. \\
\hline 7 & PaperPublish & Paper, printing and publishing & $3221-3231,48 \mathrm{~A} 000-5111 \mathrm{~A} 0$ & Paper products, publishing. \\
\hline 8 & PetrolCoal & Petroleum and coal products & 3241 & Petroleum, coal products. \\
\hline 9 & ChemRubPlast & $\begin{array}{l}\text { Chemicals, rubber and plastic } \\
\text { products }\end{array}$ & 3251-3262 & Chemicals, rubber and plastic products. \\
\hline 10 & FeMetal & Ferrous metal & $3311,3312,331510$ & Ferrous metals. \\
\hline 11 & OthMetals & Non-ferrous metals & $3313-3314,331520$ & Metals nec. \\
\hline 12 & MetalProd & Fabricated metal products & 3321-3329 & Metal products. \\
\hline
\end{tabular}

Table 2.2 continues ... 
Table 2.2 continued...

\begin{tabular}{|c|c|c|c|c|}
\hline No. & Sectors & Description & NAICS codes & Original GTAP sectors \\
\hline 13 & Autombile & Automobile manufacturing & 336111 & \multirow{9}{*}{ Motor vehicles and parts } \\
\hline 14 & MVGasEngPrts & $\begin{array}{l}\text { Motor vehicle gasoline engine } \\
\text { and engine parts } \\
\text { manufacturing }\end{array}$ & 336312 & \\
\hline 15 & MVSteerSuspn & $\begin{array}{l}\text { Motor vehicle steering, } \\
\text { suspension component } \\
\text { (except spring) } \\
\text { manufacturing }\end{array}$ & 336330 & \\
\hline 16 & MVBrakes & $\begin{array}{l}\text { Motor vehicle brakes and } \\
\text { brake systems }\end{array}$ & 336340 & \\
\hline 17 & MVPwrTrTrain & $\begin{array}{l}\text { Motor vehicle transmission } \\
\text { and power train parts }\end{array}$ & 336350 & \\
\hline 18 & MVSeatInter & $\begin{array}{l}\text { Motor vehicle interior trim, } \\
\text { seats and seat parts }\end{array}$ & 336360 & \\
\hline 19 & MVMtIStamp & Motor vehicle metal stamping & 336370 & \\
\hline 20 & OthMVParts & $\begin{array}{l}\text { Other motor vehicle parts } \\
\text { manufacturing }\end{array}$ & 336390 & \\
\hline 21 & TruckUteTrlr & $\begin{array}{l}\text { Manufacturing of trucks, } \\
\text { utility vehicles, trailers, motor } \\
\text { homes and campers. }\end{array}$ & $\begin{array}{l}\text { 336112, 336120, 336212, } \\
\text { 336213, } 336214\end{array}$ & \\
\hline 22 & OthTransEq & $\begin{array}{l}\text { All other transportation } \\
\text { equipment manufacturing }\end{array}$ & 3364-3369 & Transport equipment nec. \\
\hline 23 & ElectrnicsEq & Electronic equipment & 3341-3345 & Electronic equipment. \\
\hline 24 & OthMachEq & $\begin{array}{l}\text { Other machinery and } \\
\text { equipment }\end{array}$ & 3331-3339, 3346-3359,3391, & Machinery and equipment nec. \\
\hline 25 & OthManuf & $\begin{array}{l}\text { Other manufacturing products, } \\
\text { n.e.c. }\end{array}$ & $3371-3379$ & Manufactures nec. \\
\hline 26 & Services & Services & $2211-2334,4200-8140$ & $\begin{array}{l}\text { Electricity; Gas manufacture, distribution; Water; Construction; Trade; } \\
\text { Transport nec; Water transport; Air transport; Communication; Financial } \\
\text { services nec; Insurance; Business services nec; Recreational and other } \\
\text { services; Public administration, defense, education, health; Dwellings.. }\end{array}$ \\
\hline
\end{tabular}




\section{Endogenous variables in the disaggregation equation system for mvh}

In formal terms, we estimate for 2015 the U.S. dollar values of:

- $\operatorname{VQ}(n, s)$ for $n \in M V H, s \in O T H R E G$ where MVH is the set of 9 mvh industries/commodities; $\mathrm{VQ}(\mathrm{n}, \mathrm{s})$ is the value of output of commodity $n$ in region s; and OTHREG is the set of 8 regions in Table 1.1 excluding Canada and the U.S. We do not estimate VQ(n,US) and VQ(n,Canada). These are known from detailed input-output data for the two countries.

- $\quad \mathrm{Z}(\mathrm{n}, \mathrm{j}, \mathrm{s})$ for $\mathrm{n}, \mathrm{j} \in \mathrm{MVH}, \mathrm{s} \in \mathrm{OTHREG}$ where $\mathrm{Z}(\mathrm{n}, \mathrm{j}, \mathrm{s})$ is the value of mvh product $\mathrm{n}$ (domestic plus imported) flowing to mvh industry $\mathrm{j}$ in region s. For $\mathrm{s}=\mathrm{US}$ and Canada, $\mathrm{Z}(\mathrm{n}, \mathrm{j}, \mathrm{s})$ is known from detailed input-output data.

- $\quad Z d o m(n, j, s)$ and Zimp(n,j,s) for $n, j \in M V H, ~ s \in O T H R E G$ where Zdom(n,j,s) and Zimp(n,j,s) are the values of the flows of domestically produced and imported mvh-commodity $n$ to mvh-industry $\mathrm{j}$ in region $\mathrm{s}$. For $\mathrm{s}=$ US and Canada, Zdom(n,j,s) and Zimp(n,j,s) are known from detailed input-output data.

- $\quad \mathrm{OD}(\mathrm{n}, \mathrm{f}, \mathrm{s})$ for $\mathrm{n} \in \mathrm{MVH}, \mathrm{f} \in \mathrm{NonMVH}, \mathrm{s} \in \mathrm{OTHREG}$ where OD(n,f,s), other domestic demand, is the value of mvh-commodity $n$ (domestic plus imported) used in region $\mathrm{s}$ by domestic purchaser $\mathrm{f}$ in the set NonMVH. This is the set of domestic purchasers outside the mvh sector. These are non-mvh industries and final demanders (households, capital creators and government but not exports). For s = US and Canada, OD(n,f,s) is known from detailed input-output data.

- $\quad \operatorname{ODdom}(n, f, s)$ and ODimp(n,f,s) for $n \in M V H, f \in$ NonMVH, seOTHREG where ODdom(n,f,s) and ODimp(n,f,s) are the values of domestically produced and imported mvh-commodity n used in region s by domestic purchaser $\mathrm{f}$ in the set NonMVH. For s = US and Canada, ODdom(n,f,s) and ODimp(n,f,s) are known from detailed input-output data.

- $\quad$ DABS(n,d) for $n \in M V H, d \in O T H R E G$ where DABS(n,d) is the value of total absorption (domestic plus imported) of mvhcommodity $\mathrm{n}$ in region $\mathrm{d}$. For $\mathrm{s}=\mathrm{US}$ and Canada, DABS(n,d) is known from detailed input-output data.

We also estimate

- $\quad \operatorname{ADJ}(n, d)$ for $n \in M V H, d \in O T H R E G$ where $\operatorname{ADJ}(n, d)$ is an adjustment factor on demand for and supply of mvhcommodity $n$ in region $d$. As we will see shortly, this factor is used to adjust our initial estimates of demand and supply variables to align estimates of absorption in each region based on supply (output plus imports less exports) and demand (intermediate and final use excluding exports). A value of $\mathrm{ADJ}(\mathrm{n}, \mathrm{d})$ of greater than one adjusts demand variables up and supply variables down.

- $\quad \operatorname{Auscan}_{\text {un, }}(\mathrm{j})$ for $n, j \in \mathrm{MVH}$ where $\operatorname{Auscan}(n, j)$ is the average input-output coefficient for Canada and the U.S. for the use of mvh-commodity $n$ in mvh-industry $j$. These average input-output coefficients are calculated from detailed input-output data for the two countries. 
- $\quad \operatorname{MSH}(n, d)$ for $n \in M V H, d \in O T H R E G$ where MSH(n,d) is the share of the absorption of mvh-commodity $n$ in region $d$ accounted for by imports. Import shares in U.S. and Canadian absorption of disaggregated mvh commodities are known from detailed input-output and trade data.

\section{Exogenous variables in the disaggregation equation system for mvh}

We base the estimates of the endogenous variables on values given by data or initial estimates of:

- $\quad T R(n, s, d)$ for $n \in M V H, s, d \in R E G$, where REG is the set of 10 regions in Table 1.1; and TR(n,s,d) is the value of commodity $\mathrm{n}$ exported from region $\mathrm{s}$ to region $\mathrm{d}$.

- $\operatorname{VQuscan}(\mathrm{n})$ for $\mathrm{n} \in \mathrm{MVH}$, where VQuscan(n) is the aggregate value, calculated from U.S. and Canadian input-output data updated to 2015, of input n produced in the two countries.

- $\quad Z_{u s C a n}(n, j)$ for $n, j \in M V H$

where $Z_{U S C A N}(n, j)$ is the aggregate value, calculated from U.S. and Canadian inputoutput data updated to 2015, of input $\mathrm{n}$ (domestic plus imported if $\mathrm{n}$ is a commodity) used in the production of $\mathrm{j}$ in the two countries.

- $\quad$ VQ1(n,s) for $n \in M V H, s \in O T H R E G$ where VQ1(n,s) is our initial estimate of the value of commodity n produced in region $\mathrm{s}$.

- OD1(n,f,s) for $\mathrm{n} \in \mathrm{MVH}, \mathrm{f} \in \mathrm{NonMVH}, \mathrm{s} \in \mathrm{OTHREG}$

where OD1(n,f,s) is our initial estimate of the value of commodity n (domestic plus imported) used by purchaser $\mathrm{f}$ in region $\mathrm{s}$.

We make the estimates using the equation system listed below. In this system the variables to be estimated are in black normal type. The variables we take as given are in red italics.

Equation system for disaggregating mvh in the NATIONAL matrices: (2.1) to (2.11)

Absorption of mvh-commodity $\mathrm{n}$ in region d calculated as imports + output - exports

$$
\operatorname{DABS}(\mathrm{n}, \mathrm{d})=\sum_{\substack{\mathrm{s} \in \mathrm{Reg} \\ \mathrm{s} \neq \mathrm{d}}} T R(\mathrm{n}, \mathrm{s}, \mathrm{d})+\mathrm{VQ}(\mathrm{n}, \mathrm{d})-\sum_{\substack{\mathrm{s} \in \mathrm{Reg} \\ \mathrm{s} \neq \mathrm{d}}} T R(\mathrm{n}, \mathrm{d}, \mathrm{s}) \quad \text { for all } \mathrm{n} \in \mathrm{MVH}, \mathrm{d} \in \mathrm{OTHREG}
$$

Absorption of mvh-commodity $\mathrm{n}$ in region d calculated as intermediate demands in the mvh sector and demand outside the mvh sector

$$
\text { DABS(n, d) }=\sum_{\mathrm{j} \in \mathrm{MVH}} \mathrm{Z}(\mathrm{n}, \mathrm{j}, \mathrm{d})+\sum_{\mathrm{f} \in \mathrm{NonMVH}} \mathrm{OD}(\mathrm{n}, \mathrm{f}, \mathrm{d}) \quad \text { for all } \mathrm{n} \in \mathrm{MVH}, \mathrm{d} \in \mathrm{OTHREG}
$$

Calculation of mvh-mvh input-output coefficients from U.S. and Canadian input-output data.

$$
A_{\text {USCAN }}(n, j)=\frac{Z_{U S C A N}(n, j)}{V Q_{U S C A N}(j)} \quad \text { for all } n, j \in M V H
$$

Intermediate use of mvh-commodity $\mathrm{n}$ in mvh-industry $\mathrm{j}$ in region d estimated by applying $\mathrm{US} /$ Canada input-output coefficients and adjusting to reconcile absorption of $\mathrm{n}$ in $\mathrm{d}$ calculated by (2.1) and (2.2):

$$
\mathrm{Z}(\mathrm{n}, \mathrm{j}, \mathrm{d})=\mathrm{A}_{\text {USCAN }}(\mathrm{n}, \mathrm{j}) * \operatorname{VQ}(\mathrm{j}, \mathrm{d}) * \operatorname{ADJ}(\mathrm{n}, \mathrm{d}) \quad \text { for all } \mathrm{n}, \mathrm{j} \in \mathrm{MVH}, \mathrm{d} \in \mathrm{OTHREG}
$$


Other (NonMVH) demands for $\mathrm{n}$ in region $\mathrm{d}$ after adjustment:

$$
\mathrm{OD}(\mathrm{n}, \mathrm{f}, \mathrm{d})=\mathrm{OD} 1(\mathrm{n}, \mathrm{f}, \mathrm{d}) * \mathrm{ADJ}(\mathrm{n}, \mathrm{d}) \quad \text { for all } \mathrm{n} \in \mathrm{MVH}, \mathrm{f} \in \mathrm{NonMVH}, \mathrm{d} \in \mathrm{OTHREG}
$$

Output of $n$ in $d$ after adjustment:

$$
\mathrm{VQ}(\mathrm{n}, \mathrm{d})=\frac{V Q 1(\mathrm{n}, \mathrm{d})}{\operatorname{ADJ}(\mathrm{n}, \mathrm{d})} \quad \text { for all } \mathrm{n} \in \mathrm{MVH}, \mathrm{d} \in \text { OTHREG }
$$

Calculation of the shares in d's absorption of mvh commodity $\mathrm{n}$ accounted for by imports:

$$
\operatorname{MSH}(\mathrm{n}, \mathrm{d})=\frac{\sum_{\mathrm{s} \in \mathrm{REG}, \mathrm{s} \neq \mathrm{d}} \operatorname{TR}(\mathrm{n}, \mathrm{s}, \mathrm{d})}{\operatorname{DABS}(\mathrm{n}, \mathrm{d})} \quad \text { for all } \mathrm{n} \in \mathrm{MVH}, \mathrm{d} \in \text { OTHREG }
$$

Calculations of import and domestic flows of mvh-commodities to users in region $\mathrm{d}$ :

$$
\begin{aligned}
& \text { Zimp(n, j, d) }=Z(n, j, d) * \operatorname{MSH}(n, d) \quad \text { for all } n, j \in M V H, d \in \text { OTHREG } \\
& \text { Zdom(n, j, d) }=Z(n, j, d)-Z i m p(n, j, d) \quad \text { for all } n, j \in M V H, d \in \text { OTHREG } \\
& \text { ODimp(n,f,d)=OD(n,f,d)*MSH(n,d), } n \in \text { MVH, f } \in \text { NonMVH, d } \in \text { OTHREG } \\
& \text { ODdom(n,f,d)=OD(n,f,d)-ODimp(n,f,d), } n \in M V H, f \in \text { NonMVH, d } \in \text { OTHREG }
\end{aligned}
$$

\section{Solving the equation system}

Substituting from (2.3), (2.4), (2.5) and (2.6) into (2.1) and (2.2) gives

$$
\begin{aligned}
& \sum_{\substack{s \in \operatorname{Reg} \\
\mathrm{s} d \mathrm{~d}}} T R(\mathrm{n}, \mathrm{s}, \mathrm{d})+\frac{V Q 1(\mathrm{n}, \mathrm{d})}{\operatorname{ADJ}(\mathrm{n}, \mathrm{d})}-\sum_{\substack{\mathrm{s} \in \mathrm{Reg} \\
\mathrm{s} \neq \mathrm{d}}} T R(\mathrm{n}, \mathrm{d}, \mathrm{s}) \\
& =\sum_{\mathrm{j} \in \mathrm{MVH}} \frac{Z_{U S C A N}(\mathrm{n}, \mathrm{j})}{V Q_{U S C A N}(\mathrm{j})} * \frac{V Q 1(\mathrm{j}, \mathrm{d})}{\operatorname{ADJ}(\mathrm{j}, \mathrm{d})} * \operatorname{ADJ}(\mathrm{n}, \mathrm{d})+\sum_{\mathrm{f} \in \operatorname{NonMVH}} O D 1(\mathrm{n}, \mathrm{f}, \mathrm{d}) * \operatorname{ADJ}(\mathrm{n}, \mathrm{d}) \\
& \text { for all } \mathrm{n} \in \mathrm{MVH} \text { and } \mathrm{d} \in \text { OTHREG }
\end{aligned}
$$

The values of the adjustment factors, ADJ(n,d) can be computed from (2.12). Once they have been computed the values of all the other unknowns in (2.1) - (2.11) can be determined recursively.

\section{Deriving the GTAP-MVH database by applying SplitCom}

Using the solution from (2.1) to (2.11), we can compute splitting shares that can be presented to SplitCom. This is a program created by Horridge (2008a \& b). Users of SplitCom nominate the GTAP sectors to be disaggregated and the shares by which entries in the relevant columns and rows of the NATIONAL matrix for region d should be allocated to the disaggregated subindustries and subcommodities. Having made an initial allocation, SplitCom undertakes a RAS procedure to ensure that the disaggregated database meets balance conditions and the condition that disaggregated cells add to the values in the original database. Table 2.3 shows the splitting shares, $(a)$ to $(e)$, that we used on the different parts of the GTAP NATIONAL matrix for region d (Table 2.1, Part A) in creating the NATIONAL matrix for region d in GTAP-MVH.

\subsection{Disaggregation data}

To apply the theory described in subsection 2.1, we need to assemble TRADE matrices for disaggregated mvh products [TR(n,s,d)] and to make informed initial estimates for outputs of disaggregated mvh products in each region [VQ1(n,d)] and non-export demands for these products outside the mvh sector [OD1(n,f,d)]. 
Table 2.3. Splitting shares for creation of database for GTAP-MVH

\begin{tabular}{|c|c|c|}
\hline & $\begin{array}{l}\text { Cell in original GTAP } \\
\text { database }\end{array}$ & Splitting share \\
\hline (a) & $\begin{array}{l}\text { Diagonal flow } \\
\text { Domestic mvh-mvh flow } \\
\text { for region d }\end{array}$ & $\begin{array}{r}\operatorname{Zdom}(\mathrm{n}, \mathrm{j}, \mathrm{d}) / \sum_{\mathrm{m} \in \mathrm{MVH}} \sum_{\mathrm{k} \in \mathrm{MVH}} \mathrm{Zdom}(\mathrm{m}, \mathrm{k}, \mathrm{d}) \\
\mathrm{n}, \mathrm{j} \in \mathrm{MVH}\end{array}$ \\
\hline (b) & $\begin{array}{l}\text { Diagonal flow } \\
\text { Imported mvh-mvh flow } \\
\text { for region d }\end{array}$ & $\begin{array}{r}\operatorname{Zimp}(\mathrm{n}, \mathrm{j}, \mathrm{d}) / \sum_{\mathrm{m} \in \mathrm{MVH}} \sum_{\mathrm{k} \in \mathrm{MVH}} \operatorname{Zimp}(\mathrm{m}, \mathrm{k}, \mathrm{d}) \\
\mathrm{n}, \mathrm{j} \in \mathrm{MVH}\end{array}$ \\
\hline (c) & $\begin{array}{l}\text { Rest of mvh domestic row } \\
\text { Domestic mvh flow to user } \\
\text { f outside MVH (excluding } \\
\text { exports) in region d }\end{array}$ & $\begin{array}{r}\operatorname{ODdom}(\mathrm{n}, \mathrm{f}, \mathrm{d}) / \sum_{\mathrm{m} \in \mathrm{MVH}} \mathrm{ODdom}(\mathrm{m}, \mathrm{f}, \mathrm{d}) \\
\mathrm{n} \in \mathrm{MVH}\end{array}$ \\
\hline (d) & $\begin{array}{l}\text { Rest of mvh import row } \\
\text { Imported mvh flow to user } \\
\text { f outside MVH (excluding } \\
\text { exports) in region d }\end{array}$ & $\begin{array}{r}\operatorname{ODimp}(\mathrm{n}, \mathrm{f}, \mathrm{d}) / \sum_{\mathrm{m} \in \mathrm{MVH}} \operatorname{ODimp}(\mathrm{m}, \mathrm{f}, \mathrm{d}) \\
\mathrm{n} \in \mathrm{MVH}\end{array}$ \\
\hline (e) & $\begin{array}{l}\text { Rest of mvh column } \\
\text { Primary factor flows and } \\
\text { flows of domestic and } \\
\text { imported non-mvh } \\
\text { intermediate inputs to the } \\
\text { mvh industry in region d }\end{array}$ & $\begin{array}{l}\mathrm{VQ}(\mathrm{n}, \mathrm{d}) / \sum_{\mathrm{m} \in \mathrm{MVH}} \mathrm{VQ}(\mathrm{m}, \mathrm{d}) \\
\\
\mathrm{n} \in \mathrm{MVH}\end{array}$ \\
\hline
\end{tabular}

\footnotetext{
* Rather than using outputs as the basis for splitting shares for non-mvh inputs to mvh industries, a potentially preferable approach would be to use outputs multiplied by U.S.-Canada input-output coefficients.
}

\section{Trade data}

The first data requirement for applying the theory described in subsection 2.1 is TRADE matrices for disaggregated mvh products [TR(n,s,d)].

We downloaded data for 2015 on import and export values for mvh products at the 6-digit HS (Harmonised code) level for the year 2015 from the COMTRADE database (UN Comtrade 2018, Chapters 84 and 87). For each trade flow, the data show fob values, export taxes, import tariffs and international transport margins. We developed the disaggregated mvh TRADE matrices on the basis of fob values.

The main task in using the Comtrade data was to map and aggregate it into the $9 \mathrm{mvh}$ commodities in 10 GTAP-MVH. To do this, we developed the concordance between 6-digit HS codes and GTAP-MVH commodities shown in Table 2.4. The concordance is based on Aguiar (2016) and a careful examination of HS codes and their descriptions, as well as the descriptions of the mvh commodities in NAICS (United States Census Bureau 2017).

The COMTRADE data come in the form EXPORTS(c,s,d), i.e. exports of commodity $c$ from reporting region $s$ to partner region $d$, and IMPORTS(c,s,d), i.e. imports of $c$ to reporting region $d$ from partner region $s$. In principle, after conversion to compatible valuation bases, these two types of data must match, i.e. for the same commodity $c$ and the same country pair 
Table 2.4. Concordance between mvh commodities in GTAP-MVH and 6-digit HS codes

\begin{tabular}{|c|c|c|}
\hline \multicolumn{2}{|c|}{$\begin{array}{l}\text { mvh commodities in } \\
\text { GTAP-MVH }\end{array}$} & \multirow{2}{*}{$\begin{array}{l}\text { HS code } \\
8702 \text { (Motorvehicles for the transport of ten or more persons, } \\
\text { including the driver) } \\
8703 \text { (Motor cars and other motor vehicles principally designed for the } \\
\text { transport of persons, including station wagons and racing cars.) } \\
8706 \text { (chassis fitted with engines, for motor vehicles) }\end{array}$} \\
\hline 13 & $\begin{array}{l}\text { Automobile } \\
\text { manufacturing }\end{array}$ & \\
\hline 14 & $\begin{array}{l}\text { Motor vehicle } \\
\text { gasoline engine and } \\
\text { engine parts } \\
\text { manufacturing }\end{array}$ & $\begin{array}{l}840731-840734,840820,840891,840899 \text { (Spark ignition } \\
\text { reciprocating piston engines and parts) }\end{array}$ \\
\hline 15 & $\begin{array}{l}\text { Motor vehicle } \\
\text { steering, suspension } \\
\text { component (except } \\
\text { spring) manufacturing }\end{array}$ & $\begin{array}{l}870880 \text { (Suspension systems and parts thereof) } \\
870894 \text { (Steering wheels, columns, boxes) }\end{array}$ \\
\hline 16 & $\begin{array}{l}\text { Motor vehicle brakes } \\
\text { and brake systems }\end{array}$ & 870830 (Brakes and servo-brakes of motor vehicle) \\
\hline 17 & $\begin{array}{l}\text { Motor vehicle } \\
\text { transmission and } \\
\text { power train parts }\end{array}$ & $\begin{array}{l}870840 \text { (Gear boxes and parts thereof) } \\
870850 \text { (Drive-axles with differential, whether/not provided with other } \\
\text { transmission components, \& non-driving axles; parts thereof of the } \\
\text { motor vehicles of headings } 87.01 \text { to } 87.05 \text {.) }\end{array}$ \\
\hline 18 & $\begin{array}{l}\text { Motor vehicle interior } \\
\text { trim, seats and seat } \\
\text { parts }\end{array}$ & $\begin{array}{l}870821 \text { (Safety seat belts for motor vehicles) } \\
870870 \text { (Road wheels and parts and accessories thereof) }\end{array}$ \\
\hline 19 & $\begin{array}{l}\text { Motor vehicle metal } \\
\text { stamping (fenders, } \\
\text { tops, body parts, trim, } \\
\text { and molding) }\end{array}$ & $\begin{array}{l}8707 \text { (Bodies (including cabs), for the motor vehicles of headings } \\
87.01 \text { to } 87.05 \text { ) } \\
870810 \text { (Bumpers and parts) } \\
870829 \text { (Parts \& accessories of bodies (incl. cabs) of the motor } \\
\text { vehicles of } 87.01-87.05, \text { n.e.s. in } 87.08 \text { ) }\end{array}$ \\
\hline 20 & $\begin{array}{l}\text { Other motor vehicle } \\
\text { parts manufacturing }\end{array}$ & $\begin{array}{l}870891 \text { (Radiators and parts) } \\
870892 \text { (Silencers and exhaust pipes) } \\
870893 \text { (Clutches and parts thereof, for tractors) } \\
870895 \text { (Safety airbags with inflator system) } \\
870899 \text { (Other parts \& accessories for motor vehicle) }\end{array}$ \\
\hline 21 & $\begin{array}{l}\text { Truck, utility vehicle, } \\
\text { trailer, motor home, } \\
\text { travel trailer and } \\
\text { camper manufacturing }\end{array}$ & $\begin{array}{l}870120 \text { (Road tractors for semitrailers) } \\
8704 \text { (Motor vehicles for the transport of goods.) } \\
8705 \text { (Special purpose motor vehicles, other than those principally } \\
\text { designed for the transport of persons or goods (for example, } \\
\text { breakdown lorries, crane lorries, fire fighting vehicles, concrete-mixer } \\
\text { lorries, road sweeper lorries, spraying lorries, mobile work) } \\
8709 \text { (Works trucks, self-propelled, not fitted with lifting or handling } \\
\text { equipment, of the type used in factories, warehouses, dock areas or } \\
\text { airports for short distance transport of goods; tractors of the type used } \\
\text { on railway station platforms; parts of the fore) } \\
8710 \text { (Tanks and other armoured fighting vehicles, motorised, whether } \\
\text { or not fitted with weapons, and parts of such vehicles.) } \\
8716 \text { (Trailers and semi-trailers; other vehicles, not mechanically } \\
\text { propelled; parts thereof.) excl. } 871680 \text { (Other vehicles, not } \\
\text { mechanically propelled, nes) }\end{array}$ \\
\hline
\end{tabular}

s,d, we expect EXPORTS(c,s,d) = IMPORTS (c,s,d). However, it is well-known that there are discrepancies in these data (see, for example, Gelhar 1996, Ferrantino et al. 2012, Shaar 2017), which can be quite large.

There are several approaches handling import/export discrepancies. Gelhar (1996) and Shaar (2017) compile reliability and data quality indices for all countries, and then accept the reported trade flows of the more reliable partner in each country pair. Calderon et al. (2007) give primacy to the data reported by the country with the higher income in each country pair. Here we adopted the second approach. Among GTAP-MVH's 10 regions, we consider the U.S., Canada, Japan, South Korea, Germany, EU26 and the UK as higher income countries, 
and the remaining regions (Mexico, China and RoW) as lower income countries. For trade flows from higher income countries to lower income countries, we adopted export values reported by the higher income countries. For trade flows from lower income countries to higher income countries, we adopted import values reported by higher income countries. For trade flows amongst similar income level country pairs, we adopted the average values of imports and exports.

To complete the preparation of the TRADE matrices for mvh products in GTAP-MVH, we scaled to ensure that when aggregated over all mvh products

$$
\sum_{n \in M V H} \operatorname{TR}(n, s, d)=T_{R} R_{\text {GTAP }}(m v h, s, d) \quad \text { for all } s, d \in R E G, s \neq d
$$

where $\operatorname{TR}_{\mathrm{GTAP}}(\mathrm{mvh}, \mathrm{s}, \mathrm{d})$ is the value of mvh exports from $\mathrm{s}$ to $\mathrm{d}$ in the original GTAP database.

\section{Data to inform our initial estimates for outputs [VQ1(n,d)] and non-export demands for mvh products outside the mvh sector [OD1 $(n, f, d)]$}

For Canada, input-output data identifies outputs and other demands for all 9 disaggregated mvh commodities/industries (see Statistics Canada, 2017). For the U.S., input-output data for these disaggregated commodities/industries is almost complete (see Dixon et al., 2017). Consequently, for these two countries we do not need initial estimates of outputs and other demands as inputs to (2.1) to (2.11). Instead, as can be seen in these equations, we use inputoutput data from Canada and the U.S. to help us make judgement about input-output coefficients in the mvh sector for other countries.

For Japan, China and South Korea, shares of disaggregated mvh outputs and other demands in total mvh outputs and other demand were calculated directly from input-output data. These countries have useful levels of disaggregation for mvh in their input-output data, but less than the 9 commodities/industries required. In these cases, we used U.S.-Canada shares to complete the splits. For example, the Japanese input-output data distinguishes 4 mvh commodities/industries: (i) Automobiles; (ii) Trucks, utility vehicles, and trailers; (iii) Mvh gas engines and parts; and (iv) Other motor vehicle parts, see Ministry of Internal Affairs and Communications (2016). The first 3 industries are the same as those required for GTAP$\mathrm{MVH}$. The last industry is an aggregation of the 6 remaining required mvh commodities/industries. We used the shares of these 6 in their aggregate sector from the U.S.Canada database to split the corresponding aggregate sector in the Japanese data into the 6 required mvh commodities/industries. ${ }^{3}$

For the remaining countries/regions (Mexico, Germany, EU26, the UK and RoW) shares of disaggregated mvh outputs and other demands in total mvh outputs and other demands were calculated starting from data published by the United Nations Industrial Development Organization (UNIDO 2018). These data provide information on 2 mvh sectors: (i) Cars, trucks and trailers, and (ii) Parts and accessories for motor vehicles. We disaggregated the parts commodity in the UNIDO data into ' $M V$ gas engines' and 'Other MV parts', using data from Barnes reports (Barnes reports 2017a-c). At this stage, we had 3 mvh commodities. These were disaggregated to the required 9 using the average U.S.-Canada shares.

\footnotetext{
3 The Chinese input-output database contains 2 mvh industries, namely Motor vehicles and MV parts, see Mai et al. (2010). The South Korean input-output database contains 3 mvh industries, namely Motor vehicles; Mvh gas engines; and Mvh parts, see Bank of Korea (2014).
} 
While the use of the U.S.-Canada shares in assisting in the splits of outputs and demands for other countries is not ideal, it should be recalled that we are using this method only to obtain initial estimates, VQ1(n,d) and OD1(n,f,d) for $\mathrm{n} \in \mathrm{MVH}, \mathrm{f} \in \mathrm{NonMVH}, \mathrm{d} \in \mathrm{OTHREG}$. These initial estimates are modified in our equation system (2.1) to (2.11) taking account of detailed disaggregated data on trade.

\subsection{Sales matrices for disaggregated mvh products: outcomes of the disaggregation procedures}

Tables 2.5a - 2.5i contain sales matrices for the 9 mvh commodities in GTAP-MVH valued at market prices (production costs in the producing country). These are TRADE matrices with diagonal flows added to show intra-region sales. The tables were generated by disaggregating GTAP data for 2015 using the disaggregation procedures described in subsections 2.1 and 2.2. For each commodity, the rows in the tables show sales from source regions where the commodity is produced, and the columns show the destination regions where the commodity is used. The row totals show output values of the commodity in the source regions. The column totals show absorption values of the commodity in the destination regions.

The tables show that, apart from the finished product Automobiles, the main destination for a country's motor vehicle commodities is usually the country itself. Exceptions include the production of Gasoline engines by Mexico and the UK, and the production Trucks etc by Canada and Mexico. In the case of Automobiles, the principal user is often outside the source country. For example, the U.S. is the principal user of Automobiles produced by Canada and Mexico. Rest of World is the principal user of Automobiles produced by Japan and South Korea. EU26 is the principal user of Automobiles produced by Germany and the UK. EU26, RoW, China and Germany are the biggest producers of Automobiles, while the U.S. and China are the biggest producers of Trucks, utility vehicles, trailers, motor homes and campers. Japan and China are the biggest producers of nearly all mvh components.

The tables can be converted to percentages in either the row direction or the column direction to highlight sales and demand patterns. We can also create new tables to highlight the data for all products for a particular country. This is done in Table 3.3 which shows destination percentages in the sales of Canadian mvh products. The table shows that the U.S. is by far the biggest export market for Canadian mvh products. Exports to the U.S. account for more than half of Canadian Automobiles and Trucks etc, and over a third of Canadian Gasoline engines and Other motor vehicle parts. In total, exports to the U.S. account for 51.9 per cent of Canada's mvh output and 92 per cent of Canada's mvh exports ( $=100 * 51.9 / 56.4)$. RoW and Mexico rank second and third among export markets for Canada's mvh products. But exports to these markets account for only small shares of Canadian output (1.8 and 1.5 per cent).

\section{Illustrative GTAP-MVH simulations}

During 2017 and 2018, mainly at the behest of the U.S., the 3 NAFTA countries held lengthy trade negotiations. Numerous proposals were made, particularly with regard to the motor vehicle sector. In this section, we show how GTAP-MVH can be used to provide information to negotiators. We simulate the effects of two proposed sets of changes to the powers of the tariffs applying to imports of finished motor vehicles (commodities $13 \& 21$ in GTAP-MVH, see Table 2.2). In simulation 1 we impose the percentage increases in intraNAFTA tariffs shown in the upper part of Table 3.1. In simulation 2, we impose the same 
Table 2.5a. Automobiles: flows from source to destination (US\$million, 2015)

\begin{tabular}{|c|c|c|c|c|c|c|c|c|c|c|c|}
\hline \multicolumn{2}{|c|}{ Destination } & \multirow[b]{2}{*}{2 Canada } & \multirow[b]{2}{*}{3 Mexico } & \multirow[b]{2}{*}{4 Japan } & \multirow[b]{2}{*}{5 SKorea } & \multirow[b]{2}{*}{6 China } & \multirow[b]{2}{*}{7 Germany } & \multirow[b]{2}{*}{8 EU26 } & \multirow[b]{2}{*}{9 UK } & \multirow[b]{2}{*}{10 RoW } & \multirow[b]{2}{*}{ Total } \\
\hline Source & 1 USA & & & & & & & & & & \\
\hline 1 USA & 108861 & 4853 & 2173 & 257 & 99 & 1048 & 690 & 455 & 204 & 4033 & 122673 \\
\hline 2 Canada & 11422 & 8223 & 429 & 26 & 18 & 211 & 33 & 126 & 24 & 651 & 21162 \\
\hline 3 Mexico & 14612 & 1812 & 8892 & 142 & 45 & 517 & 1293 & 382 & 132 & 3971 & 31799 \\
\hline 4 Japan & 26910 & 3149 & 2434 & 30372 & 1297 & 13937 & 2270 & 7067 & 3636 & 51363 & 142435 \\
\hline 5 South Korea & 7090 & 1127 & 512 & 517 & 7016 & 3727 & 617 & 3802 & 456 & 23507 & 48370 \\
\hline 6 China & 1090 & 116 & 79 & 604 & 197 & 155089 & 212 & 503 & 251 & 5197 & 163338 \\
\hline 7 Germany & 11770 & 1610 & 988 & 3414 & 1355 & 13406 & 17908 & 59032 & 17564 & 34460 & 161507 \\
\hline 8 EU26 & 3239 & 361 & 486 & 1298 & 500 & 4009 & 27226 & 112011 & 18159 & 29217 & 196506 \\
\hline $9 \mathrm{UK}$ & 2364 & 250 & 77 & 454 & 113 & 2201 & 3468 & 10286 & 8603 & 8229 & 36046 \\
\hline 10 RoW & 2455 & 276 & 784 & 1450 & 249 & 655 & 2774 & 6667 & 1813 & 159014 & 176136 \\
\hline Total & 189814 & 21778 & 16856 & 38534 & 10890 & 194798 & 56491 & 200331 & 50841 & 319641 & 1099973 \\
\hline
\end{tabular}

Table 2.5b. Motor vehicle gasoline engine and engine parts: flows from source to destination (US\$million, 2015)

\begin{tabular}{|c|c|c|c|c|c|c|c|c|c|c|c|}
\hline \multicolumn{2}{|c|}{ Destination } & \multirow[b]{2}{*}{2 Canada } & \multirow[b]{2}{*}{3 Mexico } & \multirow[b]{2}{*}{ 4 Japan } & \multirow[b]{2}{*}{5 SKorea } & \multirow[b]{2}{*}{6 China } & \multirow[b]{2}{*}{7 Germany } & \multirow[b]{2}{*}{8 EU26 } & \multirow[b]{2}{*}{9 UK } & \multirow[b]{2}{*}{10 RoW } & \multirow[b]{2}{*}{ Total } \\
\hline Source & 1 USA & & & & & & & & & & \\
\hline 1 USA & 24153 & 3046 & 2486 & 145 & 154 & 838 & 603 & 246 & 42 & 1521 & 33233 \\
\hline 2 Canada & 2233 & 3390 & 195 & 6 & 11 & 67 & 12 & 27 & 2 & 98 & 6040 \\
\hline 3 Mexico & 2606 & 414 & 2494 & 29 & 26 & 149 & 408 & 75 & 10 & 544 & 6754 \\
\hline 4 Japan & 1827 & 274 & 385 & 41840 & 277 & 1531 & 273 & 527 & 103 & 2675 & 49713 \\
\hline 5 South Korea & 545 & 111 & 92 & 45 & 9458 & 464 & 84 & 321 & 15 & 1385 & 12520 \\
\hline 6 China & 720 & 98 & 122 & 455 & 412 & 65596 & 248 & 365 & 69 & 2636 & 70720 \\
\hline 7 Germany & 1691 & 295 & 330 & 563 & 618 & 3129 & 14116 & 9329 & 1055 & 3796 & 34921 \\
\hline 8 EU26 & 659 & 93 & 229 & 301 & 324 & 1330 & 9863 & 29025 & 1544 & 4563 & 47933 \\
\hline 9 UK & 402 & 54 & 30 & 88 & 62 & 611 & 1053 & 1926 & 1154 & 1074 & 6454 \\
\hline 10 RoW & 555 & 79 & 410 & 373 & 179 & 241 & 1115 & 1657 & 171 & 32488 & 37270 \\
\hline Total & 35391 & 7854 & 6772 & 43845 & 11521 & 73957 & 27774 & 43498 & 4165 & 50779 & 305558 \\
\hline
\end{tabular}


Table 2.5c. Motor vehicle steering and suspension components: flows from source to destination (US\$million, 2015)

\begin{tabular}{|c|c|c|c|c|c|c|c|c|c|c|c|}
\hline \multicolumn{12}{|c|}{ Destination } \\
\hline Source & 1 USA & 2 Canada & 3 Mexico & 4 Japan & 5 SKorea & 6 China & 7 Germany & 8 EU26 & $9 \mathrm{UK}$ & 10 RoW & Total \\
\hline 1 USA & 12106 & 710 & 482 & 22 & 17 & 167 & 90 & 40 & 8 & 229 & 13870 \\
\hline 2 Canada & 405 & 1748 & 34 & 1 & 1 & 12 & 2 & 4 & 0 & 13 & 2220 \\
\hline 3 Mexico & 641 & 118 & 845 & 5 & 3 & 36 & 74 & 15 & 2 & 100 & 1841 \\
\hline 4 Japan & 244 & 43 & 49 & 15113 & 21 & 204 & 27 & 57 & 13 & 269 & 16038 \\
\hline 5 South Korea & 128 & 30 & 21 & 8 & 3000 & 108 & 15 & 61 & 3 & 244 & 3617 \\
\hline 6 China & 224 & 35 & 36 & 106 & 71 & 21295 & 57 & 91 & 20 & 616 & 22552 \\
\hline 7 Germany & 304 & 62 & 57 & 76 & 62 & 559 & 4978 & 1347 & 176 & 511 & 8132 \\
\hline 8 EU26 & 125 & 21 & 42 & 43 & 34 & 250 & 1384 & 9090 & 272 & 647 & 11909 \\
\hline $9 \mathrm{UK}$ & 38 & 6 & 3 & 6 & 3 & 58 & 74 & 147 & 856 & 77 & 1269 \\
\hline 10 RoW & 120 & 20 & 85 & 61 & 22 & 52 & 179 & 288 & 34 & 11651 & 12511 \\
\hline Total & 14335 & 2792 & 1654 & 15440 & 3235 & 22741 & 6879 & 11140 & 1385 & 14357 & 93958 \\
\hline
\end{tabular}

Table 2.5d. Motor vehicle brakes and brake systems: flows from source to destination (US\$million, 2015)

\begin{tabular}{|c|c|c|c|c|c|c|c|c|c|c|c|}
\hline \multicolumn{2}{|c|}{ Destination } & \multirow[b]{2}{*}{2 Canada } & \multirow[b]{2}{*}{3 Mexico } & \multirow[b]{2}{*}{4 Japan } & \multirow[b]{2}{*}{5 SKorea } & \multirow[b]{2}{*}{6 China } & \multirow[b]{2}{*}{7 Germany } & \multirow[b]{2}{*}{8 EU26 } & \multirow[b]{2}{*}{9 UK } & \multirow[b]{2}{*}{10 RoW } & \multirow[b]{2}{*}{ Total } \\
\hline Source & 1 USA & & & & & & & & & & \\
\hline 1 USA & 6800 & 282 & 171 & 8 & 7 & 45 & 40 & 17 & 3 & 90 & 7463 \\
\hline 2 Canada & 121 & 751 & 9 & 0 & 0 & 3 & 1 & 1 & 0 & 4 & 891 \\
\hline 3 Mexico & 237 & 46 & 492 & 2 & 1 & 10 & 32 & 6 & 1 & 38 & 865 \\
\hline 4 Japan & 108 & 20 & 20 & 7958 & 9 & 64 & 14 & 28 & 6 & 123 & 8350 \\
\hline 5 South Korea & 64 & 16 & 10 & 4 & 1592 & 38 & 9 & 34 & 2 & 126 & 1892 \\
\hline 6 China & 225 & 37 & 34 & 100 & 73 & 10370 & 67 & 101 & 20 & 638 & 11666 \\
\hline 7 Germany & 160 & 34 & 28 & 38 & 33 & 209 & 2664 & 788 & 93 & 279 & 4326 \\
\hline 8 EU26 & 80 & 14 & 25 & 26 & 22 & 113 & 1038 & 4768 & 173 & 427 & 6685 \\
\hline 9 UK & 40 & 6 & 3 & 6 & 4 & 43 & 91 & 170 & 323 & 83 & 769 \\
\hline 10 RoW & 47 & 8 & 31 & 22 & 9 & 14 & 81 & 124 & 13 & 6369 & 6717 \\
\hline Total & 7882 & 1214 & 824 & 8164 & 1751 & 10907 & 4037 & 6037 & 634 & 8176 & 49624 \\
\hline
\end{tabular}


Table 2.5e. Motor vehicle transmission and power train parts: flows from source to destination (US\$million, 2015)

\begin{tabular}{|c|c|c|c|c|c|c|c|c|c|c|c|}
\hline \multicolumn{2}{|c|}{ Destination } & \multirow[b]{2}{*}{2 Canada } & \multirow[b]{2}{*}{3 Mexico } & \multirow[b]{2}{*}{4 Japan } & \multirow[b]{2}{*}{5 SKorea } & \multirow[b]{2}{*}{6 China } & \multirow[b]{2}{*}{7 Germany } & \multirow[b]{2}{*}{8 EU26 } & \multirow[b]{2}{*}{$9 \mathrm{UK}$} & \multirow[b]{2}{*}{10 RoW } & \multirow[b]{2}{*}{ Total } \\
\hline Source & 1 USA & & & & & & & & & & \\
\hline 1 USA & 30558 & 2492 & 2154 & 99 & 117 & 1224 & 406 & 196 & 35 & 1095 & 38376 \\
\hline 2 Canada & 937 & 3453 & 77 & 2 & 4 & 44 & 4 & 10 & 1 & 32 & 4563 \\
\hline 3 Mexico & 2123 & 299 & 2768 & 17 & 17 & 193 & 243 & 53 & 7 & 346 & 6068 \\
\hline 4 Japan & 3022 & 404 & 599 & 36192 & 377 & 4028 & 330 & 756 & 154 & 3461 & 49323 \\
\hline 5 South Korea & 618 & 112 & 98 & 38 & 8432 & 837 & 70 & 316 & 15 & 1229 & 11764 \\
\hline 6 China & 294 & 35 & 46 & 137 & 138 & 67093 & 74 & 129 & 26 & 840 & 68812 \\
\hline 7 Germany & 1347 & 209 & 249 & 332 & 406 & 3975 & 13675 & 6442 & 759 & 2364 & 29757 \\
\hline 8 EU26 & 340 & 43 & 112 & 116 & 138 & 1091 & 3727 & 24809 & 720 & 1838 & 32933 \\
\hline $9 \mathrm{UK}$ & 137 & 16 & 10 & 22 & 17 & 332 & 262 & 568 & 2058 & 285 & 3709 \\
\hline 10 RoW & 297 & 38 & 207 & 149 & 79 & 205 & 437 & 769 & 83 & 30053 & 32317 \\
\hline Total & 39671 & 7102 & 6320 & 37104 & 9725 & 79024 & 19227 & 34048 & 3858 & 41543 & 277622 \\
\hline
\end{tabular}

Table 2.5f. Motor vehicle interior trim, seats and seat parts: flows from source to destination (US\$million, 2015)

\begin{tabular}{|c|c|c|c|c|c|c|c|c|c|c|c|}
\hline \multicolumn{2}{|c|}{ Destination } & \multirow[b]{2}{*}{2 Canada } & \multirow[b]{2}{*}{3 Mexico } & \multirow[b]{2}{*}{4 Japan } & \multirow[b]{2}{*}{5 SKorea } & \multirow[b]{2}{*}{6 China } & \multirow[b]{2}{*}{7 Germany } & \multirow[b]{2}{*}{8 EU26 } & \multirow[b]{2}{*}{$9 \mathrm{UK}$} & \multirow[b]{2}{*}{10 RoW } & \multirow[b]{2}{*}{ Total } \\
\hline Source & 1 USA & & & & & & & & & & \\
\hline 1 USA & 20237 & 1038 & 398 & 56 & 19 & 127 & 161 & 53 & 8 & 225 & 22322 \\
\hline 2 Canada & 276 & 3261 & 12 & 1 & 1 & 4 & 1 & 2 & 0 & 5 & 3563 \\
\hline 3 Mexico & 435 & 72 & 1934 & 6 & 2 & 12 & 55 & 8 & 1 & 41 & 2565 \\
\hline 4 Japan & 53 & 8 & 5 & 35709 & 3 & 21 & 6 & 10 & 2 & 35 & 35853 \\
\hline 5 South Korea & 86 & 18 & 7 & 8 & 6465 & 34 & 11 & 33 & 1 & 99 & 6763 \\
\hline 6 China & 490 & 69 & 40 & 362 & 105 & 40142 & 136 & 163 & 28 & 805 & 42340 \\
\hline 7 Germany & 191 & 35 & 18 & 75 & 26 & 164 & 12012 & 693 & 70 & 193 & 13477 \\
\hline 8 EU26 & 111 & 16 & 19 & 61 & 21 & 104 & 1351 & 12631 & 154 & 346 & 14813 \\
\hline $9 \mathrm{UK}$ & 25 & 4 & 1 & 7 & 1 & 18 & 54 & 80 & 869 & 31 & 1090 \\
\hline 10 RoW & 138 & 20 & 50 & 110 & 17 & 28 & 226 & 272 & 25 & 13132 & 14018 \\
\hline Total & 22043 & 4542 & 2485 & 36395 & 6659 & 40652 & 14013 & 13945 & 1159 & 14910 & 156803 \\
\hline
\end{tabular}


Table 2.5g. Motor vehicle metal stamping: flows from source to destination (US\$million, 2015)

\begin{tabular}{|c|c|c|c|c|c|c|c|c|c|c|c|}
\hline $\begin{array}{l}\text { Destinati } \\
\text { Source }\end{array}$ & 1 USA & 2 Canada & 3 Mexico & 4 Japan & 5 SKorea & 6 China & 7 Germany & 8 EU26 & $9 \mathrm{UK}$ & 10 RoW & Total \\
\hline 1 USA & 19696 & 1155 & 758 & 37 & 28 & 316 & 175 & 67 & 9 & 330 & 22571 \\
\hline 2 Canada & 439 & 4513 & 213 & 5 & 8 & 91 & 12 & 26 & 2 & 76 & 5385 \\
\hline 3 Mexico & 354 & 387 & 2182 & 18 & 12 & 139 & 291 & 50 & 5 & 291 & 3728 \\
\hline 4 Japan & 99 & 102 & 114 & 40665 & 50 & 567 & 77 & 140 & 23 & 571 & 42409 \\
\hline 5 South Korea & 77 & 108 & 72 & 30 & 7170 & 452 & 63 & 225 & 9 & 776 & 8980 \\
\hline 6 China & 74 & 69 & 68 & 213 & 141 & 55891 & 132 & 183 & 29 & 1060 & 57861 \\
\hline 7 Germany & 170 & 204 & 182 & 259 & 208 & 2148 & 12614 & 4614 & 434 & 1500 & 22333 \\
\hline 8 EU26 & 68 & 66 & 129 & 142 & 111 & 928 & 5267 & 19119 & 647 & 1835 & 28312 \\
\hline 9 UK & 23 & 21 & 10 & 23 & 12 & 237 & 312 & 538 & 1034 & 239 & 2448 \\
\hline 10 RoW & 67 & 66 & 271 & 207 & 72 & 198 & 701 & 980 & 84 & 20076 & 22723 \\
\hline Total & 21066 & 6691 & 3998 & 41598 & 7812 & 60967 & 19643 & 25943 & 2276 & 26753 & 216749 \\
\hline
\end{tabular}

Table 2.5h. Other motor vehicle parts: flows from source to destination (US\$million, 2015)

\begin{tabular}{|c|c|c|c|c|c|c|c|c|c|c|c|}
\hline \multicolumn{2}{|c|}{ Destination } & \multirow[b]{2}{*}{2 Canada } & \multirow[b]{2}{*}{3 Mexico } & \multirow[b]{2}{*}{4 Japan } & \multirow[b]{2}{*}{5 SKorea } & \multirow[b]{2}{*}{6 China } & \multirow[b]{2}{*}{7 Germany } & \multirow[b]{2}{*}{8 EU26 } & \multirow[b]{2}{*}{$9 \mathrm{UK}$} & \multirow[b]{2}{*}{10 RoW } & \multirow[b]{2}{*}{ Total } \\
\hline Source & 1 USA & & & & & & & & & & \\
\hline 1 USA & 46474 & 9667 & 8058 & 498 & 439 & 3228 & 2131 & 1128 & 182 & 6147 & 77952 \\
\hline 2 Canada & 3855 & 5104 & 163 & 5 & 8 & 66 & 10 & 32 & 2 & 102 & 9348 \\
\hline 3 Mexico & 5421 & 411 & 5850 & 31 & 23 & 179 & 448 & 107 & 13 & 681 & 13164 \\
\hline 4 Japan & 2318 & 166 & 238 & 71213 & 150 & 1116 & 182 & 458 & 85 & 2047 & 77973 \\
\hline 5 South Korea & 3238 & 314 & 265 & 140 & 11846 & 1587 & 264 & 1307 & 56 & 4966 & 23985 \\
\hline 6 China & 1833 & 119 & 151 & 600 & 448 & 111871 & 334 & 637 & 115 & 4047 & 120153 \\
\hline 7 Germany & 3138 & 262 & 300 & 541 & 490 & 3336 & 30865 & 11839 & 1263 & 4245 & 56279 \\
\hline 8 EU26 & 1771 & 120 & 302 & 421 & 373 & 2053 & 14013 & 64390 & 2682 & 7383 & 93506 \\
\hline 9 UK & 642 & 41 & 24 & 74 & 42 & 559 & 887 & 2100 & 5087 & 1030 & 10486 \\
\hline 10 RoW & 1233 & 84 & 446 & 431 & 171 & 308 & 1312 & 2524 & 246 & 64499 & 71255 \\
\hline Total & 69922 & 16288 & 15797 & 73954 & 13989 & 124303 & 50448 & 84521 & 9732 & 95148 & 554101 \\
\hline
\end{tabular}


Table 2.5i. Trucks, utility vehicles, trailers, motor homes and campers: flows from source to destination (US\$million, 2015)

\begin{tabular}{|c|c|c|c|c|c|c|c|c|c|c|c|}
\hline \multicolumn{2}{|c|}{ Destination } & \multirow[b]{2}{*}{2 Canada } & \multirow[b]{2}{*}{3 Mexico } & \multirow[b]{2}{*}{4 Japan } & \multirow[b]{2}{*}{5 SKorea } & \multirow[b]{2}{*}{6 China } & \multirow[b]{2}{*}{7 Germany } & \multirow[b]{2}{*}{8 EU26 } & \multirow[b]{2}{*}{9 UK } & \multirow[b]{2}{*}{10 RoW } & \multirow[b]{2}{*}{ Total } \\
\hline Source & 1 USA & & & & & & & & & & \\
\hline 1 USA & 260896 & 23877 & 5898 & 548 & 337 & 1318 & 2610 & 1838 & 630 & 16180 & 314132 \\
\hline 2 Canada & 33973 & 14597 & 371 & 18 & 20 & 85 & 40 & 163 & 24 & 834 & 50124 \\
\hline 3 Mexico & 28325 & 1856 & 15612 & 63 & 32 & 135 & 1011 & 320 & 85 & 3309 & 50748 \\
\hline 4 Japan & 8853 & 551 & 232 & 104567 & 153 & 605 & 298 & 998 & 393 & 7241 & 123892 \\
\hline 5 South Korea & 2122 & 179 & 44 & 35 & 30840 & 147 & 74 & 489 & 45 & 3012 & 36986 \\
\hline 6 China & 4870 & 275 & 103 & 612 & 320 & 243739 & 381 & 970 & 370 & 9964 & 261606 \\
\hline 7 Germany & 8290 & 602 & 202 & 538 & 344 & 1242 & 79734 & 17817 & 4045 & 10376 & 123188 \\
\hline 8 EU26 & 3993 & 235 & 174 & 358 & 223 & 652 & 13454 & 149363 & 7311 & 15387 & 191151 \\
\hline $9 \mathrm{UK}$ & 861 & 48 & 8 & 36 & 15 & 104 & 502 & 1595 & 26195 & 1275 & 30639 \\
\hline 10 RoW & 4272 & 253 & 396 & 571 & 158 & 152 & 1948 & 5000 & 1037 & 227306 & 241095 \\
\hline Total & 356456 & 42473 & 23042 & 107345 & 32443 & 248179 & 100052 & 178551 & 40135 & 294884 & 1423560 \\
\hline
\end{tabular}

Table 2.6. Regional allocation of sales of Canadian-produced motor vehicle commodities (\% in 2015)

\begin{tabular}{|c|c|c|c|c|c|c|c|c|c|c|c|}
\hline $\begin{array}{l}\text { Region } \\
\text { mvh commodity }\end{array}$ & 1 USA & 2 Canada & 3 Mexico & 4 Japan & 5 SKorea & 6 China & 7 Germany & 8 EU26 & $9 \mathrm{UK}$ & 10 RoW & Total \\
\hline 1 Automobile & 54.0 & 38.9 & 2.0 & 0.1 & 0.1 & 1.0 & 0.2 & 0.6 & 0.1 & 3.1 & 100.0 \\
\hline 2 MVGasEngPrts & 37.0 & 56.1 & 3.2 & 0.1 & 0.2 & 1.1 & 0.2 & 0.4 & 0.0 & 1.6 & 100.0 \\
\hline 3 MVSteerSuspn & 18.2 & 78.8 & 1.5 & 0.0 & 0.1 & 0.5 & 0.1 & 0.2 & 0.0 & 0.6 & 100.0 \\
\hline 4 MVBrakes & 13.6 & 84.3 & 1.1 & 0.0 & 0.0 & 0.3 & 0.1 & 0.1 & 0.0 & 0.5 & 100.0 \\
\hline 5 MVPwrTrTrain & 20.5 & 75.7 & 1.7 & 0.0 & 0.1 & 1.0 & 0.1 & 0.2 & 0.0 & 0.7 & 100.0 \\
\hline 6 MVSeatInter & 7.7 & 91.5 & 0.3 & 0.0 & 0.0 & 0.1 & 0.0 & 0.1 & 0.0 & 0.2 & 100.0 \\
\hline 7 MVMtlStamp & 8.1 & 83.8 & 4.0 & 0.1 & 0.1 & 1.7 & 0.2 & 0.5 & 0.0 & 1.4 & 100.0 \\
\hline 8 OthMVParts & 41.2 & 54.6 & 1.7 & 0.1 & 0.1 & 0.7 & 0.1 & 0.3 & 0.0 & 1.1 & 100.0 \\
\hline 9 TruckUteTrlr & 67.8 & 29.1 & 0.7 & 0.0 & 0.0 & 0.2 & 0.1 & 0.3 & 0.0 & 1.7 & 100.0 \\
\hline All mvh commodities & 51.9 & 43.6 & 1.5 & 0.1 & 0.1 & 0.6 & 0.1 & 0.4 & 0.1 & 1.8 & 100.0 \\
\hline
\end{tabular}


Table 3.1. Proposed percentage increases in powers of tariffs on finished vehicles: commodities 13 \& 21 in GTAP-MVH

\begin{tabular}{|c|c|c|c|}
\hline \multirow[b]{2}{*}{$\begin{array}{l}\text { on imports } \\
\text { from: }\end{array}$} & \multicolumn{3}{|c|}{ Tariff imposed by: } \\
\hline & U.S. & Canada & Mexico \\
\hline & \multicolumn{3}{|c|}{ Shocks in simulation 1} \\
\hline U.S. & & 2.5 & 10.8 \\
\hline Canada & 0.7 & & 6.4 \\
\hline \multirow[t]{2}{*}{ Mexico } & 1.1 & 3.1 & \\
\hline & \multicolumn{3}{|c|}{ Additional shock in simulation 2} \\
\hline $\begin{array}{l}\text { Non-NAFTA } \\
\text { countries }\end{array}$ & 25.0 & 0.0 & 0.0 \\
\hline
\end{tabular}

increases as in simulation 1 plus a 25 per cent increase in the power of the U.S. tariff on imports of finished vehicles from non-NAFTA countries. Because the initial tariff rates are zero or close to zero, the increases in Table 3.1 are the new levels of tariff rates.

For simulation purposes, we treat the tariffs as though they were imposed in 2016. Tables 3.2 and 3.3 show effects from simulations 1 and 2 on outputs in the 10 regions of GTAP-MVH for: the motor vehicle sector as a whole; finished motor vehicles (commodities 13 \& 21); and motor vehicle parts (commodities 14 to 20). Regional macro effects from the two simulations are in Tables 3.4 and 3.5. All effects are expressed as percentage deviations from a baseline in which there are no tariff changes. While we don't explain the baseline or GTAP-MVH theory here ${ }^{4}$, key features will be apparent from our explanation of the results.

\section{Simulation 1: output effects in the MVH sector (Table 3.2)}

Output of motor vehicles and parts declines in the three NAFTA countries. While the motor vehicle sector in each of the three countries benefits from reduced competition from its NAFTA partners, it suffers an offsetting effect from reduced demand from its NAFTA partners. So why are the overall effects negative? This is because non-NAFTA countries gain market share in NAFTA destinations: in this simulation non-NAFTA countries do not suffer a tariff increase on their exports to NAFTA. The gain in market share for non-NAFTA countries in NAFTA markets explains why the motor vehicle sector is stimulated in nonNAFTA countries.

Because the tariffs are applied only on finished vehicles, the negative effects on the production of finished vehicles in NAFTA are larger than those for parts. Nevertheless, parts production generally declines in the three NAFTA countries, reflecting reductions in sales to NAFTA's finished vehicles industries.

Against the general pattern of the other results, output of parts in Mexico initially increases slightly (0.034 per cent in 2016, Table 3.2). At the macro level, Mexico experiences a bigger real devaluation than the other two NAFTA countries: Mexico is more dependent on motor vehicle exports than the other two countries. Greater real devaluation allows the Mexican parts sector to compete successfully outside NAFTA. This slight positive effect is offset in

4 Details of the baseline and theory of GTAP-MVH can be found in our working paper (Dixon et al. 2019). 
the long run by continuing negative adjustment in the finished motor vehicle industry in the NAFTA countries, reducing demand for Mexican parts within NAFTA.

Continuing negative adjustment of the finished motor vehicle industries in the NAFTA countries is caused by gradual downward adjustment in their capital stocks.

\section{Simulation 2: output effects in the MVH sector (Table 3.3)}

This simulation imposes two sets of shocks: (a) the quite small intra-NAFTA tariff shocks that were applied in the first simulation; and (b) a 25 per cent U.S. tariff against imports of finished vehicles from non-NAFTA countries. The second set of shocks is dominant in most of our results.

The U.S. tariff on finished motor vehicles from non-NAFTA countries stimulates output of both finished goods and parts in the U.S. It also has a generally stimulatory effect in the motor vehicle sector in the other two NAFTA countries. Output of finished motor vehicles in these countries benefits from reduced competition in the U.S. market from non-NAFTA countries. Parts production in Canada benefits from expansion in its own finished motor vehicle industry and that of the U.S.

The results for parts production in Mexico in the early years of the simulation are negative. This is explained by a symmetrical argument to that given for the result for Mexican parts production in Table $3.2 \mathrm{f}$. This time Mexico is a major beneficiary from the U.S. tariff on finished vehicles (includes trucks) from non-NAFTA countries. Associated real appreciation of the Mexican currency initially hurts its parts sales outside Mexico.

Motor vehicle production in non-NAFTA countries shows strongly negative effects, especially for Japan for which the U.S. is a major market (see Table 2.5a).

\section{Simulation 1: Regional macro results (Table 3.4)}

In the short run, raising tariffs within NAFTA reduces GDP in the NAFTA countries but increases GDP for other countries, which gain from diversion of demand by NAFTA countries away from their NAFTA partners. The NAFTA countries lose by increasing the costs of finished cars \& trucks to their households and capital creators. These increases in costs reduce the number of people who can be employed at current real wages. Eventually wages adjust down so that employment in the NAFTA countries is restored gradually to baseline. This process is complete by 2023 for the U.S. and Canada, but still has some distance to go for Mexico. Even though the employment effects are eliminated in the long run, the GDP deviations for the NAFTA countries remain negative. This is because the NAFTA countries lose capital in the long run. With higher tariffs, capital must become more scarce for rates of return to be restored to baseline levels, or explained another way, reduced real wages mean that an economy's K/L ratio will fall implying, with L returning to baseline, a long-run reduction in $\mathrm{K}$.

The final panel in Table 3.4 shows percentage deviations in private and public consumption, which we assume move together. These deviations can be interpreted as welfare effects. In the long run, the intra-NAFTA tariffs reduce the welfare of all three NAFTA countries. Outside NAFTA the results are generally positive. Most of the non-NAFTA countries (or regions) identified in GTAP-MVH benefit from terms-of-trade improvements associated with improved competitiveness in NAFTA markets.

\section{Simulation 2: Regional macro results (Table 3.5)}

Raising tariffs on finished motor vehicles imported from outside NAFTA reduces employment in the U.S. in the short run (-0.078 per cent in 2016) and capital in the long run (-0.145 per cent in 2023). The explaining mechanisms can be understood from our commentary on $\mathrm{K}$ and L movements in Table 3.4. Together, the labor and capital effects leave U.S. GDP reduced by the policy in both the short and long run. 
For Canada and Mexico, the GDP effects in simulation 2 are positive in both the short and long run. In the short run, both countries experience employment gains associated with their improved competitiveness in the U.S. motor vehicle market and in the long run both countries experience increases in their capital stock associated with higher real wages.

For Canada, the long-run employment effect is slightly negative (-0.006 per cent in 2023). As illustrated in Figure 3.1, this is a very minor effect and should not be considered either policy relevant or reliable. What is reliable is that aggregate employment in the long run returns closely to baseline. Sometimes in our modeling, which involves difference equations, the return of employment to baseline exhibits damped oscillations of the type apparent in the figure.

For Japan and South Korea, the macro effects of the U.S. tariff against their exports of finished motor vehicles are negative. Both these countries have significant exports of finished motor vehicles to the U.S. For other non-NAFTA countries, the direct effects of U.S tariffs on finished motor vehicles, while negative, are small: these countries don't export large quantities of finished motor vehicles to the U.S. For these countries, the negative direct effects can be outweighed by positive indirect effects.

There are two types of positive indirect effects for non-NAFTA countries. First, U.S. tariffs cause real appreciation in the U.S. (loss in competitiveness), reducing U.S. exports of all products (not just motor vehicles). This is a source of gain for countries that compete with the U.S. in third markets. Second, U.S. tariffs on finished vehicles from non-NAFTA counties are bad for investment in the U.S. Investment in the U.S. accounts for about 17 per cent of worldwide investment. The downward effect on U.S. investment has a noticeable effect on worldwide investment. The negative impact on worldwide investment is stronger than the negative effect on worldwide saving. Consequently, worldwide interest rates falls. This leads to extra capital in many countries. Only the U.S. and countries with a strong link to the U.S. through exports to the U.S. of finished cars have negative results for aggregate capital. Countries which gain capital, wind up with extra GDP, but not necessarily extra consumption. Their consumption can be adversely affected by negative terms of trade effects, especially if they import a lot from the U.S.

Figure 3.1. Percentage deviations for Canada in macro variables: simulation 2

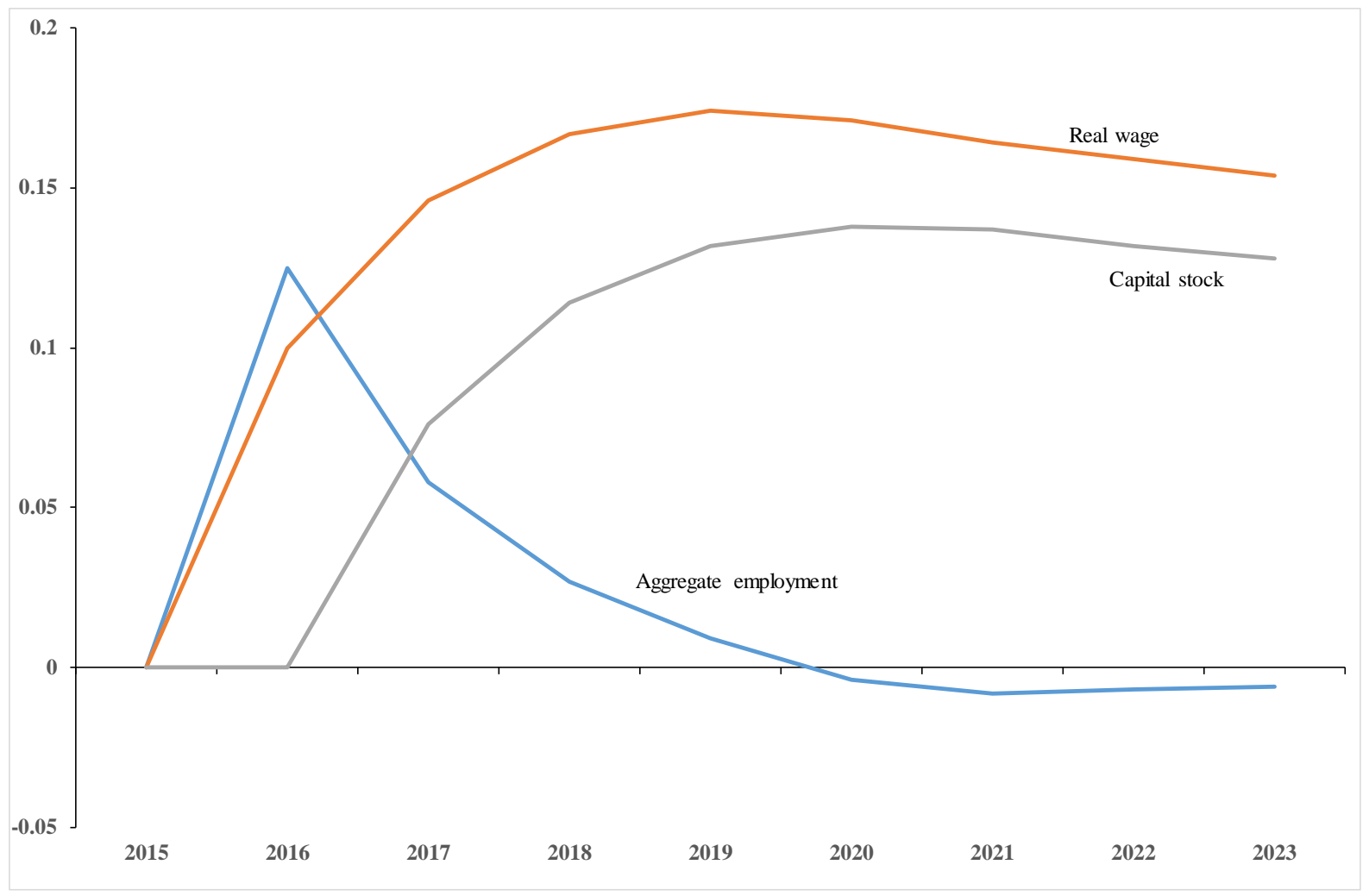


Table 3.2. Simulation 1 (tariff increases in NAFTA): percentage effects on outputs of motor vehicles

\begin{tabular}{|c|c|c|c|c|c|c|c|c|}
\hline $\begin{array}{l}\text { Motor vehicles \& } \\
\text { parts }\end{array}$ & 2016 & 2017 & 2018 & 2019 & 2020 & 2021 & 2022 & 2023 \\
\hline 1 USA & -0.360 & -0.390 & -0.397 & -0.398 & -0.398 & -0.398 & -0.399 & -0.399 \\
\hline 2 Canada & -0.169 & -0.285 & -0.369 & -0.425 & -0.456 & -0.469 & -0.472 & -0.467 \\
\hline 3 Mexico & -0.095 & -0.308 & -0.506 & -0.677 & -0.818 & -0.930 & -1.020 & -1.090 \\
\hline 4 Japan & 0.106 & 0.171 & 0.213 & 0.239 & 0.259 & 0.272 & 0.283 & 0.292 \\
\hline 5 SKorea & 0.058 & 0.099 & 0.103 & 0.154 & 0.173 & 0.189 & 0.202 & 0.213 \\
\hline 6 China & 0.033 & 0.042 & 0.047 & 0.050 & 0.051 & 0.052 & 0.053 & 0.053 \\
\hline 7 Germany & 0.127 & 0.133 & 0.141 & 0.148 & 0.152 & 0.157 & 0.160 & 0.163 \\
\hline 8 EU26 & 0.035 & 0.049 & 0.058 & 0.065 & 0.070 & 0.073 & 0.076 & 0.079 \\
\hline 9 UK & 0.085 & 0.091 & 0.099 & 0.106 & 0.111 & 0.115 & 0.119 & 0.122 \\
\hline 10 RoW & 0.036 & 0.054 & 0.065 & 0.072 & 0.077 & 0.079 & 0.081 & 0.083 \\
\hline Finished vehicles & 2016 & 2017 & 2018 & 2019 & 2020 & 2021 & 2022 & 2023 \\
\hline 1 USA & -0.484 & -0.493 & -0.482 & -0.470 & -0.463 & -0.459 & -0.457 & -0.456 \\
\hline 2 Canada & -0.260 & -0.400 & -0.488 & -0.534 & -0.547 & -0.538 & -0.519 & -0.493 \\
\hline 3 Mexico & -0.163 & -0.489 & -0.774 & -1.012 & -1.202 & -1.305 & -1.464 & -1.551 \\
\hline 4 Japan & 0.194 & 0.241 & 0.277 & 0.302 & 0.323 & 0.331 & 0.342 & 0.349 \\
\hline 5 SKorea & 0.122 & 0.190 & 0.237 & 0.272 & 0.296 & 0.314 & 0.329 & 0.340 \\
\hline 6 China & 0.060 & 0.063 & 0.068 & 0.072 & 0.073 & 0.073 & 0.073 & 0.073 \\
\hline 7 Germany & 0.179 & 0.191 & 0.203 & 0.213 & 0.218 & 0.224 & 0.228 & 0.231 \\
\hline 8 EU26 & 0.040 & 0.056 & 0.065 & 0.071 & 0.075 & 0.078 & 0.081 & 0.083 \\
\hline $9 \mathrm{UK}$ & 0.090 & 0.100 & 0.109 & 0.118 & 0.123 & 0.129 & 0.133 & 0.136 \\
\hline 10 RoW & 0.045 & 0.069 & 0.083 & 0.091 & 0.096 & 0.098 & 0.100 & 0.101 \\
\hline Vehicle parts & 2016 & 2017 & 2018 & 2019 & 2020 & 2021 & 2022 & 2023 \\
\hline 1 USA & -0.128 & -0.193 & -0.231 & -0.254 & -0.269 & -0.278 & -0.284 & -0.287 \\
\hline 2 Canada & -0.042 & -0.122 & -0.199 & -0.267 & -0.323 & -0.367 & -0.401 & -0.425 \\
\hline 3 Mexico & 0.034 & 0.033 & -0.006 & -0.056 & -0.113 & -0.171 & -0.227 & -0.280 \\
\hline 4 Japan & 0.078 & 0.146 & 0.191 & 0.217 & 0.237 & 0.251 & 0.263 & 0.271 \\
\hline 5 SKorea & 0.007 & 0.027 & 0.046 & 0.063 & 0.078 & 0.092 & 0.104 & 0.115 \\
\hline 6 China & 0.022 & 0.033 & 0.039 & 0.042 & 0.044 & 0.045 & 0.045 & 0.045 \\
\hline 7 Germany & 0.064 & 0.061 & 0.064 & 0.067 & 0.070 & 0.072 & 0.074 & 0.076 \\
\hline 8 EU26 & 0.027 & 0.037 & 0.046 & 0.054 & 0.060 & 0.065 & 0.068 & 0.072 \\
\hline $9 \mathrm{UK}$ & 0.062 & 0.055 & 0.055 & 0.056 & 0.057 & 0.058 & 0.059 & 0.060 \\
\hline 10 RoW & 0.017 & 0.022 & 0.027 & 0.031 & 0.034 & 0.037 & 0.038 & 0.040 \\
\hline
\end{tabular}


Table 3.3. Simulation 2 (tariff increases in NAFTA and U.S. tariffs on Non-NAFTA): percentage effects on outputs of motor vehicles

\begin{tabular}{|c|c|c|c|c|c|c|c|c|}
\hline $\begin{array}{l}\text { Motor vehicles \& } \\
\text { parts }\end{array}$ & 2016 & 2017 & 2018 & 2019 & 2020 & 2021 & 2022 & 2023 \\
\hline 1 USA & 4.143 & 4.713 & 5.059 & 5.168 & 5.138 & 5.045 & 4.967 & 4.89 \\
\hline 2 Canada & 4.470 & 7.878 & 10.271 & 11.888 & 12.907 & 13.505 & 13.866 & 14.068 \\
\hline 3 Mexico & 0.931 & 2.984 & 4.680 & 6.040 & 7.101 & 7.900 & 8.499 & 8.949 \\
\hline 4 Japan & -3.096 & -3.818 & -4.394 & -4.781 & -5.041 & -5.131 & -5.201 & -5.236 \\
\hline 5 SKorea & -1.412 & -2.104 & -2.643 & -3.040 & -3.309 & -3.499 & -3.638 & -3.736 \\
\hline 6 China & -0.651 & -0.803 & -0.893 & -0.933 & -0.925 & -0.911 & -0.896 & -0.880 \\
\hline 7 Germany & -2.638 & -2.647 & -2.762 & -2.812 & -2.787 & -2.776 & -2.765 & -2.751 \\
\hline 8 EU26 & -0.659 & -0.863 & -0.998 & -1.076 & -1.108 & -1.124 & -1.132 & -1.134 \\
\hline 9 UK & -2.097 & -2.282 & -2.490 & -2.613 & -2.648 & -2.681 & -2.698 & -2.706 \\
\hline 10 RoW & -0.477 & -0.650 & -0.756 & -0.812 & -0.825 & -0.821 & -0.809 & -0.795 \\
\hline Finished vehicles & 2016 & 2017 & 2018 & 2019 & 2020 & 2021 & 2022 & 2023 \\
\hline 1 USA & 5.341 & 5.779 & 5.994 & 5.966 & 5.811 & 5.620 & 5.478 & 5.355 \\
\hline 2 Canada & 7.108 & 11.98 & 15.199 & 17.192 & 18.281 & 18.770 & 18.955 & 18.960 \\
\hline 3 Mexico & 1.522 & 4.572 & 7.011 & 8.926 & 10.387 & 11.463 & 12.247 & 12.819 \\
\hline 4 Japan & -4.424 & -4.970 & -5.541 & -5.876 & -6.113 & -6.082 & -6.114 & -6.109 \\
\hline 5 SKorea & -2.620 & -3.847 & -4.721 & -5.296 & -5.612 & -5.799 & -5.911 & -5.974 \\
\hline 6 China & -0.922 & -1.148 & -1.279 & -1.337 & -1.315 & -1.291 & -1.266 & -1.242 \\
\hline 7 Germany & -3.476 & -3.649 & -3.873 & -3.968 & -3.941 & -3.926 & -3.903 & -3.878 \\
\hline 8 EU26 & -0.654 & -0.888 & -1.033 & -1.108 & -1.129 & -1.135 & -1.133 & -1.129 \\
\hline 9 UK & -2.257 & -2.528 & -2.792 & -2.944 & -2.990 & -3.028 & -3.046 & -3.054 \\
\hline 10 RoW & -0.494 & -0.725 & -0.870 & -0.948 & -0.969 & -0.965 & -0.951 & -0.932 \\
\hline Vehicle parts & 2016 & 2017 & 2018 & 2019 & 2020 & 2021 & 2022 & 2023 \\
\hline 1 USA & 1.865 & 2.643 & 3.196 & 3.557 & 3.769 & 3.871 & 3.916 & 3.925 \\
\hline 2 Canada & 0.448 & 1.450 & 2.511 & 3.513 & 4.394 & 5.115 & 5.684 & 6.121 \\
\hline 3 Mexico & -0.287 & -0.351 & -0.148 & 0.153 & 0.503 & 0.865 & 1.215 & 1.542 \\
\hline 4 Japan & -2.667 & -3.423 & -3.999 & -4.401 & -4.670 & -4.797 & -4.879 & -4.926 \\
\hline 5 SKorea & -0.483 & -0.783 & -1.076 & -1.342 & -1.575 & -1.768 & -1.926 & -2.052 \\
\hline 6 China & -0.535 & -0.670 & -0.748 & -0.784 & -0.783 & -0.775 & -0.766 & -0.754 \\
\hline 7 Germany & -1.624 & -1.415 & -1.384 & -1.367 & -1.334 & -1.322 & -1.317 & -1.309 \\
\hline 8 EU26 & -0.665 & -0.816 & -0.936 & -1.020 & -1.068 & -1.101 & -1.125 & -1.139 \\
\hline $9 \mathrm{UK}$ & -1.439 & -1.254 & -1.227 & -1.222 & -1.205 & -1.208 & -1.216 & -1.221 \\
\hline 10 RoW & -0.439 & -0.488 & -0.507 & -0.510 & -0.500 & -0.490 & -0.482 & -0.473 \\
\hline
\end{tabular}


Table 3.4. Simulation 1 (tariff increases in NAFTA): percentage deviations in macro aggregates by region

\begin{tabular}{|c|c|c|c|c|c|c|c|c|}
\hline Real GDP & 2016 & 2017 & 2018 & 2019 & 2020 & 2021 & 2022 & 2023 \\
\hline 1 USA & -0.005 & -0.003 & -0.002 & -0.002 & -0.002 & -0.002 & -0.002 & -0.002 \\
\hline 2 Canada & -0.038 & -0.030 & -0.027 & -0.025 & -0.023 & -0.021 & -0.020 & -0.020 \\
\hline 3 Mexico & -0.036 & -0.054 & -0.070 & -0.081 & -0.090 & -0.097 & -0.102 & -0.106 \\
\hline 4 Japan & 0.004 & 0.005 & 0.004 & 0.004 & 0.004 & 0.004 & 0.004 & 0.003 \\
\hline 5 SKorea & 0.006 & 0.004 & 0.004 & 0.005 & 0.005 & 0.005 & 0.005 & 0.004 \\
\hline 6 China & 0.003 & 0.001 & 0.001 & 0.002 & 0.002 & 0.002 & 0.002 & 0.001 \\
\hline 7 Germany & 0.003 & 0.002 & 0.002 & 0.002 & 0.002 & 0.002 & 0.002 & 0.001 \\
\hline 8 EU26 & 0.001 & 0.001 & 0.002 & 0.002 & 0.002 & 0.003 & 0.003 & 0.003 \\
\hline $9 \mathrm{UK}$ & 0.002 & 0.001 & 0.002 & 0.002 & 0.002 & 0.002 & 0.002 & 0.002 \\
\hline $10 \mathrm{ROW}$ & 0.000 & 0.001 & 0.002 & 0.002 & 0.002 & 0.002 & 0.002 & 0.002 \\
\hline Employment & 2016 & 2017 & 2018 & 2019 & 2020 & 2021 & 2022 & 2023 \\
\hline 1 USA & -0.007 & -0.003 & -0.002 & -0.001 & -0.001 & -0.001 & 0.000 & 0.000 \\
\hline 2 Canada & -0.052 & -0.027 & -0.014 & -0.008 & -0.004 & -0.002 & 0.000 & 0.000 \\
\hline 3 Mexico & -0.060 & -0.048 & -0.041 & -0.035 & -0.029 & -0.024 & -0.019 & -0.015 \\
\hline 4 Japan & 0.005 & 0.004 & 0.002 & 0.001 & 0.001 & 0.001 & 0.000 & 0.000 \\
\hline 5 SKorea & 0.007 & 0.003 & 0.002 & 0.001 & 0.001 & 0.001 & 0.001 & 0.000 \\
\hline 6 China & 0.003 & 0.000 & 0.000 & 0.000 & 0.000 & 0.000 & 0.000 & 0.000 \\
\hline 7 Germany & 0.005 & 0.003 & 0.002 & 0.001 & 0.001 & 0.000 & 0.000 & 0.000 \\
\hline 8 EU26 & 0.001 & 0.001 & 0.001 & 0.001 & 0.001 & 0.001 & 0.000 & 0.000 \\
\hline $9 \mathrm{UK}$ & 0.002 & 0.001 & 0.001 & 0.001 & 0.000 & 0.000 & 0.000 & 0.000 \\
\hline $10 \mathrm{ROW}$ & 0.001 & 0.001 & 0.001 & 0.001 & 0.001 & 0.000 & 0.000 & 0.000 \\
\hline Capital & 2016 & 2017 & 2018 & 2019 & 2020 & 2021 & 2022 & 2023 \\
\hline 1 USA & 0.000 & -0.003 & -0.005 & -0.005 & -0.006 & -0.006 & -0.007 & -0.007 \\
\hline 2 Canada & 0.000 & -0.031 & -0.046 & -0.054 & -0.058 & -0.060 & -0.061 & -0.061 \\
\hline 3 Mexico & 0.000 & -0.039 & -0.067 & -0.089 & -0.106 & -0.119 & -0.130 & -0.138 \\
\hline 4 Japan & 0.000 & 0.005 & 0.007 & 0.007 & 0.007 & 0.007 & 0.007 & 0.007 \\
\hline 5 SKorea & 0.000 & 0.005 & 0.006 & 0.007 & 0.008 & 0.008 & 0.008 & 0.008 \\
\hline 6 China & 0.000 & 0.003 & 0.004 & 0.004 & 0.005 & 0.005 & 0.005 & 0.005 \\
\hline 7 Germany & 0.000 & 0.003 & 0.004 & 0.004 & 0.004 & 0.004 & 0.004 & 0.004 \\
\hline 8 EU26 & 0.000 & 0.002 & 0.003 & 0.004 & 0.005 & 0.005 & 0.005 & 0.006 \\
\hline $9 \mathrm{UK}$ & 0.000 & 0.002 & 0.003 & 0.003 & 0.004 & 0.004 & 0.004 & 0.004 \\
\hline $10 \mathrm{ROW}$ & 0.000 & 0.001 & 0.002 & 0.003 & 0.004 & 0.004 & 0.004 & 0.004 \\
\hline \multicolumn{9}{|c|}{ Real private \& public consumption } \\
\hline & 2016 & 2017 & 2018 & 2019 & 2020 & 2021 & 2022 & 2023 \\
\hline 1 USA & -0.004 & -0.003 & -0.002 & -0.002 & -0.002 & -0.002 & -0.002 & -0.002 \\
\hline 2 Canada & -0.023 & -0.016 & -0.012 & -0.010 & -0.007 & -0.006 & -0.005 & -0.005 \\
\hline 3 Mexico & -0.028 & -0.035 & -0.043 & -0.047 & -0.048 & -0.049 & -0.049 & -0.049 \\
\hline 4 Japan & 0.005 & 0.005 & 0.004 & 0.003 & 0.003 & 0.003 & 0.003 & 0.003 \\
\hline 5 SKorea & 0.011 & 0.006 & 0.006 & 0.006 & 0.006 & 0.005 & 0.005 & 0.005 \\
\hline 6 China & 0.003 & 0.000 & 0.000 & 0.000 & 0.000 & 0.000 & -0.001 & -0.001 \\
\hline 7 Germany & 0.001 & 0.002 & 0.002 & 0.003 & 0.002 & 0.002 & 0.002 & 0.002 \\
\hline 8 EU26 & -0.003 & -0.001 & 0.000 & 0.000 & 0.001 & 0.001 & 0.001 & 0.001 \\
\hline $9 \mathrm{UK}$ & 0.002 & 0.002 & 0.002 & 0.002 & 0.002 & 0.002 & 0.002 & 0.002 \\
\hline $10 \mathrm{ROW}$ & -0.002 & 0.000 & 0.000 & 0.001 & 0.001 & 0.001 & 0.000 & 0.000 \\
\hline
\end{tabular}


Table 3.5. Simulation 2 (tariff increases in NAFTA and U.S. tariffs on Non-NAFTA): percentage deviations in macro aggregates by region

\begin{tabular}{|c|c|c|c|c|c|c|c|c|}
\hline Real GDP & 2016 & 2017 & 2018 & 2019 & 2020 & 2021 & 2022 & 2023 \\
\hline 1 USA & -0.092 & -0.084 & -0.076 & -0.074 & -0.075 & -0.078 & -0.079 & -0.080 \\
\hline 2 Canada & 0.104 & 0.093 & 0.087 & 0.082 & 0.075 & 0.071 & 0.070 & 0.070 \\
\hline 3 Mexico & 0.047 & 0.101 & 0.152 & 0.191 & 0.220 & 0.241 & 0.257 & 0.269 \\
\hline 4 Japan & -0.048 & -0.040 & -0.035 & -0.031 & -0.028 & -0.025 & -0.025 & -0.024 \\
\hline 5 SKorea & -0.061 & -0.052 & -0.047 & -0.043 & -0.039 & -0.037 & -0.036 & -0.035 \\
\hline 6 China & -0.005 & 0.001 & 0.004 & 0.002 & 0.000 & -0.002 & -0.004 & -0.005 \\
\hline 7 Germany & -0.055 & -0.019 & -0.001 & 0.008 & 0.014 & 0.016 & 0.016 & 0.016 \\
\hline 8 EU26 & 0.003 & 0.009 & 0.011 & 0.010 & 0.008 & 0.006 & 0.003 & 0.002 \\
\hline $9 \mathrm{UK}$ & -0.007 & 0.000 & 0.004 & 0.004 & 0.005 & 0.004 & 0.003 & 0.002 \\
\hline 10 ROW & 0.018 & 0.021 & 0.021 & 0.019 & 0.017 & 0.014 & 0.012 & 0.011 \\
\hline Employment & 2016 & 2017 & 2018 & 2019 & 2020 & 2021 & 2022 & 2023 \\
\hline 1 USA & -0.078 & -0.034 & -0.012 & -0.003 & -0.001 & 0.000 & 0.000 & 0.000 \\
\hline 2 Canada & 0.125 & 0.058 & 0.027 & 0.009 & -0.004 & -0.008 & -0.007 & -0.006 \\
\hline 3 Mexico & 0.096 & 0.057 & 0.055 & 0.048 & 0.039 & 0.031 & 0.025 & 0.020 \\
\hline 4 Japan & -0.072 & -0.043 & -0.026 & -0.016 & -0.008 & -0.004 & -0.003 & -0.002 \\
\hline 5 SKorea & -0.091 & -0.056 & -0.034 & -0.021 & -0.011 & -0.007 & -0.004 & -0.003 \\
\hline 6 China & -0.003 & 0.000 & 0.003 & 0.002 & 0.000 & -0.002 & -0.002 & -0.003 \\
\hline 7 Germany & -0.089 & -0.033 & -0.010 & 0.000 & 0.006 & 0.006 & 0.005 & 0.003 \\
\hline 8 EU26 & 0.009 & 0.002 & 0.002 & 0.001 & -0.001 & -0.002 & -0.003 & -0.003 \\
\hline $9 \mathrm{UK}$ & -0.008 & -0.010 & -0.006 & -0.004 & -0.002 & -0.002 & -0.002 & -0.002 \\
\hline $10 \mathrm{ROW}$ & 0.024 & 0.008 & 0.002 & -0.001 & -0.003 & -0.003 & -0.003 & -0.003 \\
\hline Capital & 2016 & 2017 & 2018 & 2019 & 2020 & 2021 & 2022 & 2023 \\
\hline $1 \mathrm{USA}$ & 0.000 & -0.087 & -0.124 & -0.138 & -0.143 & -0.145 & -0.145 & -0.145 \\
\hline 2 Canada & 0.000 & 0.076 & 0.114 & 0.132 & 0.138 & 0.137 & 0.132 & 0.128 \\
\hline 3 Mexico & 0.000 & 0.117 & 0.192 & 0.254 & 0.303 & 0.341 & 0.369 & 0.390 \\
\hline 4 Japan & 0.000 & -0.020 & -0.030 & -0.035 & -0.037 & -0.037 & -0.036 & -0.036 \\
\hline 5 SKorea & 0.000 & -0.025 & -0.040 & -0.049 & -0.054 & -0.056 & -0.057 & -0.056 \\
\hline 6 China & 0.000 & 0.013 & 0.013 & 0.011 & 0.007 & 0.003 & -0.001 & -0.004 \\
\hline 7 Germany & 0.000 & 0.005 & 0.014 & 0.021 & 0.026 & 0.030 & 0.032 & 0.033 \\
\hline 8 EU26 & 0.000 & 0.024 & 0.029 & 0.028 & 0.025 & 0.021 & 0.017 & 0.014 \\
\hline $9 \mathrm{UK}$ & 0.000 & 0.029 & 0.034 & 0.031 & 0.028 & 0.025 & 0.022 & 0.020 \\
\hline $10 \mathrm{ROW}$ & 0.000 & 0.030 & 0.040 & 0.041 & 0.038 & 0.034 & 0.030 & 0.026 \\
\hline \multicolumn{9}{|c|}{ Real private \& public consumption } \\
\hline & 2016 & 2017 & 2018 & 2019 & 2020 & 2021 & 2022 & 2023 \\
\hline 1 USA & -0.058 & -0.045 & -0.031 & -0.023 & -0.021 & -0.021 & -0.020 & -0.020 \\
\hline 2 Canada & 0.171 & 0.133 & 0.108 & 0.087 & 0.068 & 0.057 & 0.052 & 0.049 \\
\hline 3 Mexico & 0.241 & 0.213 & 0.221 & 0.212 & 0.198 & 0.185 & 0.175 & 0.168 \\
\hline 4 Japan & -0.085 & -0.075 & -0.065 & -0.058 & -0.053 & -0.051 & -0.052 & -0.052 \\
\hline 5 SKorea & -0.159 & -0.133 & -0.118 & -0.111 & -0.101 & -0.099 & -0.098 & -0.098 \\
\hline 6 China & -0.020 & -0.008 & -0.003 & -0.004 & -0.005 & -0.007 & -0.009 & -0.009 \\
\hline 7 Germany & -0.084 & -0.048 & -0.030 & -0.022 & -0.017 & -0.016 & -0.016 & -0.016 \\
\hline 8 EU26 & -0.008 & 0.013 & 0.022 & 0.024 & 0.022 & 0.020 & 0.017 & 0.015 \\
\hline $9 \mathrm{UK}$ & -0.006 & -0.018 & -0.017 & -0.016 & -0.015 & -0.016 & -0.016 & -0.016 \\
\hline 10 ROW & 0.020 & 0.027 & 0.026 & 0.024 & 0.021 & 0.018 & 0.017 & 0.016 \\
\hline
\end{tabular}




\section{Concluding remarks}

Trade negotiations are often conducted in terms of narrowly defined commodities, well below the commodities/industries identified in standard CGE models. Most negotiators are lawyers rather than economists. In these circumstances, CGE analyses can be dismissed because to non economists the models seem insufficiently focused on the issues at hand. This is unfortunate because even when CGE models cannot capture the exact details of a proposed trade policy, they can still provide valuable insights. These general insights are mainly of the form of alerting negotiators that increases in protection are ineffective as a macro policy. They may save jobs in the protected sector, but they reduce employment in other parts of the economy.

Disaggregating industries and commodities in a CGE model increases the likelihood that the model can be applied directly in the analysis of a particular policy. This leaves the general messages intact while at the same time increasing the acceptability of the analysis and potentially producing new policy-specific messages. For example, with the disaggregated Motor vehicle sector included in GTAP-MVH, we found that tariffs on finished motor vehicle trade within NAFTA were not only negative at a macro level for the three NAFTA countries, but were also negative for output from their Motor vehicle sectors.

The disaggregation method that we have described in this paper and implemented for the Motor vehicle sector is applicable to other sectors. In the GTAP model, it could be used to disaggregate sectors such as Textiles, Wearing apparel, Fabricated metal products, Other transport equipment, Electronic equipment, and Other machinery. Detailed trade data, necessary for our disaggregation method, exists for products within all these sectors. Disaggregating these sectors would not only enhance the GTAP model as a tool for trade policy analysis, but would also be a step towards the development of new models required for analysing trade dominated by global supply chains. ${ }^{5}$

\footnotetext{
5 Walmsley and Minor (2017) produce a version of GTAP that they refer to as a supply chain model. The standard version of GTAP identifies flows of commodity c from source country s to destination country $d$ but then assumes that the source composition of imported $\mathrm{c}$ in $\mathrm{d}$ is the same for all users. Walmsley and Minor make a valuable contribution by equipping GTAP with data that identify imports by source country for each using agent in d. However, they do not address sectoral disaggregation. We consider this to be a fundamental requirement for converting GTAP into a model for analysing global supply chain trade.
} 


\section{References}

Aguiar, A (2016), Concordances - six-digit HS sectors to GTAP sectors. GTAP Resource \#5111, available at https://www.gtap.agecon.purdue.edu/resources/res_display.asp?RecordID=5111 .

Aguiar, A., B. Narayanan, and R. McDougall (2016), “An Overview of the GTAP 9 Data Base”, Journal of Global Economic Analysis 1, no. 1, June, pp. 181-208.

Bank of Korea Economic Statistics System (2014), 2010 Updated Input-Output Tables, available at https://ecos.bok.or.kr/flex/EasySearch_e.jsp.

Barnes Reports (2017a), “Automobile \& Motor Vehicle Mfg. Industry NAICS 33611”, 2017 World Industry \& Market Outlook Report, pp 1-139.

Barnes Reports (2017b), “utomobile Gas Engine \& Engine Parts Mfg. NAICS 33631”, 2017 World Industry \& Market Outlook Report, pp 1-139.

Barnes Reports (2017c), “Heavy Duty Truck Manufacturing Industry NAICS 33612”, 2017 World Industry \& Market Outlook Report, pp 1-139.

Calderon, C., A. Chong, and E. Stein (2007), “Trade intensity and business cycle synchronization: Are developing countries any different?”, Journal of international Economics, 71, pp. 2-21.

Corong, E., T. Hertel, R. McDougall, M. Tsigas and D. van der Mensbrugghe (2017), "The standard GTAP model, version 7”, Journal of Global Economic Analysis, vol. 4, No. 1, pp.1-119.

Deardorff, A.V., R.M. Stern and C.F. Baum (1977), “A multi-country simulation of the employment and exchange-rate effects of post-Kennedy round tariff reductions", Chapter 3, pp. 36-72 in N. Akrasanee, S. Naya and V.Vichit-Vadakan (editors), Trade and Employment in Asia and the Pacific, the University Press of Hawaii, Honolulu.

Dixon, P.B., B.R. Parmenter, G.J. Ryland and J. Sutton (1977), ORANI, A General Equilibrium Model of the Australian Economy: Current Specification and Illustrations of Use for Policy Analysis, Vol. 2 of the First Progress Report of the IMPACT Project, Australian Government Publishing Service, Canberra, pp. xii + 297.

Dixon, P.B., B.R. Parmenter, John Sutton and D.P. Vincent (1982), ORANI: A Multisectoral Model of the Australian Economy, Contributions to Economic Analysis 142, NorthHolland Publishing Company, pp. xviii + 372.

Dixon, P.B., M.T. Rimmer and N. Tran (2019), "GTAP-MVH, a model for analysing the worldwide effects of trade policies in the motor vehicle sector: theory and data", CoPS Working Paper No. G-290, April, available at http://www.copsmodels.com/elecpapr/g-290.htm .

Dixon P.B, M.T. Rimmer, and Waschik., R.G. (2017) “Updating USAGE: Baseline and illustrative application”, CoPS Working Paper No. G-269, available at http://www.copsmodels.com/elecpapr/g-269.htm .

Evans, H.D. (1972), A General Equilibrium Analysis of Protection: the effects of protection in Australia, Contributions to Economic Analysis 76, North-Holland Publishing Company, Amsterdam.

Ferrantino, M.J., X. Liu, and Z. Wang (2012), "Evasion behaviors of exporters and importers: Evidence from the US-China trade data discrepancy”, Journal of International Economics, 86, pp. 141-157. 
Gehlhar, M.J. (1996), “Reconciling bilateral trade data for use in GTAP”, GTAP Technical paper No. 10, available at https://www.jgea.org/resources/download/38.pdf .

Hertel, T. W., editor, (1997), Global trade analysis: modeling and applications, Cambridge University Press, Cambridge, UK.

Horridge, J.M. (2008a,) SplitCom: Programs for splitting a GTAP sector, available at https://www.gtap.agecon.purdue.edu/resources/splitcom.asp .

Horridge, J.M. (2008b), MSplitCom: A program for splitting sectors in the GTAP database, available at https://www.copsmodels.com/msplitcom.htm .

Mai, Y-H., P.B. Dixon and M.T. Rimmer (2010), “CHINAGEM: a Monash-styled dynamic CGE model of China”, CoPS Working Paper No. G-201, June, available at http://www.copsmodels.com/elecpapr/g-201.htm .

Ministry of Internal Affairs and Communications (MIC) (2016), 2011 Input-Output Tables for Japan, available at http://www.soumu.go.jp/english/dgpp_ss/data/io/io11.htm.

Shaar, K. (2017), “Reconciling international trade data”, MPRA Paper No. 81572, available at https://mpra.ub.uni-muenchen.de/81572/ .

Statistics Canada (2017), “Supply and Use Tables for 2014”, available at https://www150.statcan.gc.ca/n1/daily-quotidien/171108/dq171108f-eng.htm

UN Comtrade (2018), United Nations Commodity Trade Statistics Database, United Nations Statistics Division, retrieved 4 Sept 2018 from https://comtrade.un.org/db/ .

UNIDO (2018) IDSB - Industrial Demand-Supply Balance Database, UNIDO (United Nations Industrial Development Organization), available at https://www.unido.org/researchers/statistical-databases

United States Census Bureau (2017), North American Industry Classification System, available at https://www.census.gov/eos/www/naics/ .

Walmsley, T. and P. Minor (2017), "Reversing NAFTA: a supply chain perspective”, ImpactECON Working paper, March, pp. 30, available at https://impactecon.com/wpcontent/uploads/2017/02/NAFTA-Festschrift-Paper-1.pdf . 